\title{
Protein arginine methylation/demethylation and cancer
}

\author{
Coralie Poulard1,2,3,4,5,6, Laura Corbo ${ }^{2,3,4,5,6}$ and Muriel Le Romancer ${ }^{2,3,4,5,6}$ \\ ${ }^{1}$ Department of Biochemistry and Molecular Biology, University of Southern California Norris Comprehensive Cancer Center, \\ University of Southern California Los Angeles, Los Angeles, CA, USA \\ ${ }^{2}$ Université de Lyon, Lyon, France \\ 3 Université Lyon 1, Lyon, France \\ ${ }^{4}$ Inserm U1052, Centre de Recherche en Cancérologie de Lyon, Lyon, France \\ ${ }^{5}$ CNRS UMR5286, Centre de Recherche en Cancérologie de Lyon, Lyon, France \\ ${ }^{6}$ Equipe Labellisée, La Ligue Contre le Cancer, Paris, France \\ Correspondence to: Muriel Le Romancer, email: muriel.leromancer@lyon.unicancer.fr
}

Keywords: PRMT, JMJD6, methylation, demethylation, cancer

Received: March 14, $2016 \quad$ Accepted: August 09, $2016 \quad$ Published: August 18, 2016

\section{ABSTRACT}

Protein arginine methylation is a common post-translational modification involved in numerous cellular processes including transcription, DNA repair, mRNA splicing and signal transduction. Currently, there are nine known members of the protein arginine methyltransferase (PRMT) family, but only one arginine demethylase has been identified, namely the Jumonji domain-containing 6 (JMJD6). Although its demethylase activity was initially challenged, its dual activity as an arginine demethylase and a lysine hydroxylase is now recognized. Interestingly, a growing number of substrates for arginine methylation and demethylation play key roles in tumorigenesis. Though alterations in the sequence of these enzymes have not been identified in cancer, their overexpression is associated with various cancers, suggesting that they could constitute targets for therapeutic strategies. In this review, we present the recent knowledge of the involvement of PRMTs and JMJD6 in tumorigenesis.

\section{INTRODUCTION}

Protein methylation was first described in early $1960 \mathrm{~s}$, with the discovery of $\varepsilon$-N-methyl-lysine in the flagellar protein of Salmonella typhimurium [1]. The methylation of lysine residues of histones, was subsequently unveiled several years later [2]. At the beginning of the 1970s, protein methylation of arginine residues was also uncovered by different groups [35]. This post-translational modification (PTM) is catalyzed by a family of enzymes called protein arginine methyltransferases (PRMTs). The first enzyme, namely PRMT1, was identified at the end of the 1990s [6], twenty years after the first observation of arginine methylation. During the decade that followed, controversy arose over the reversibility of methylation, since no demethylases had been identified. Indeed, some authors described methylation as a static and stable mark [7-9], opposed to those that believed in a cyclic and transient process $[10,11]$. This initial controversy was suspended with the discovery of deiminase enzymes, which catalyze the demethylimination reaction and convert arginine residues into citrulline $[12,13]$. However, these enzymes are not regarded as demethylases, since they convert unmodified and monomethylated arginine into citrulline, instead of actually producing a non-modified arginine residue. This controversy finally ended in 2007 when the first and still unique arginine demethylase, namely Jumonji domaincontaining 6 (JMJD6), [14] was identified. Nevertheless, the function of this novel enzyme also rapidly became a matter of controversy, and it was finally ascribed two distinct functions, namely as an arginine demethylase [14] and a lysyl-hydroxylase [15].

In the present review, we will summarize the current knowledge on arginine methylation/demethylation, including the controversy on the bifunctional JMJD6. In addition, we will particularly focus on the link between these processes and cancer. Indeed, although arginine methylation is associated with the regulation of many biological pathways (see Table 2, for review $[16,17]$ ), 
Table 1: PRMTs family members

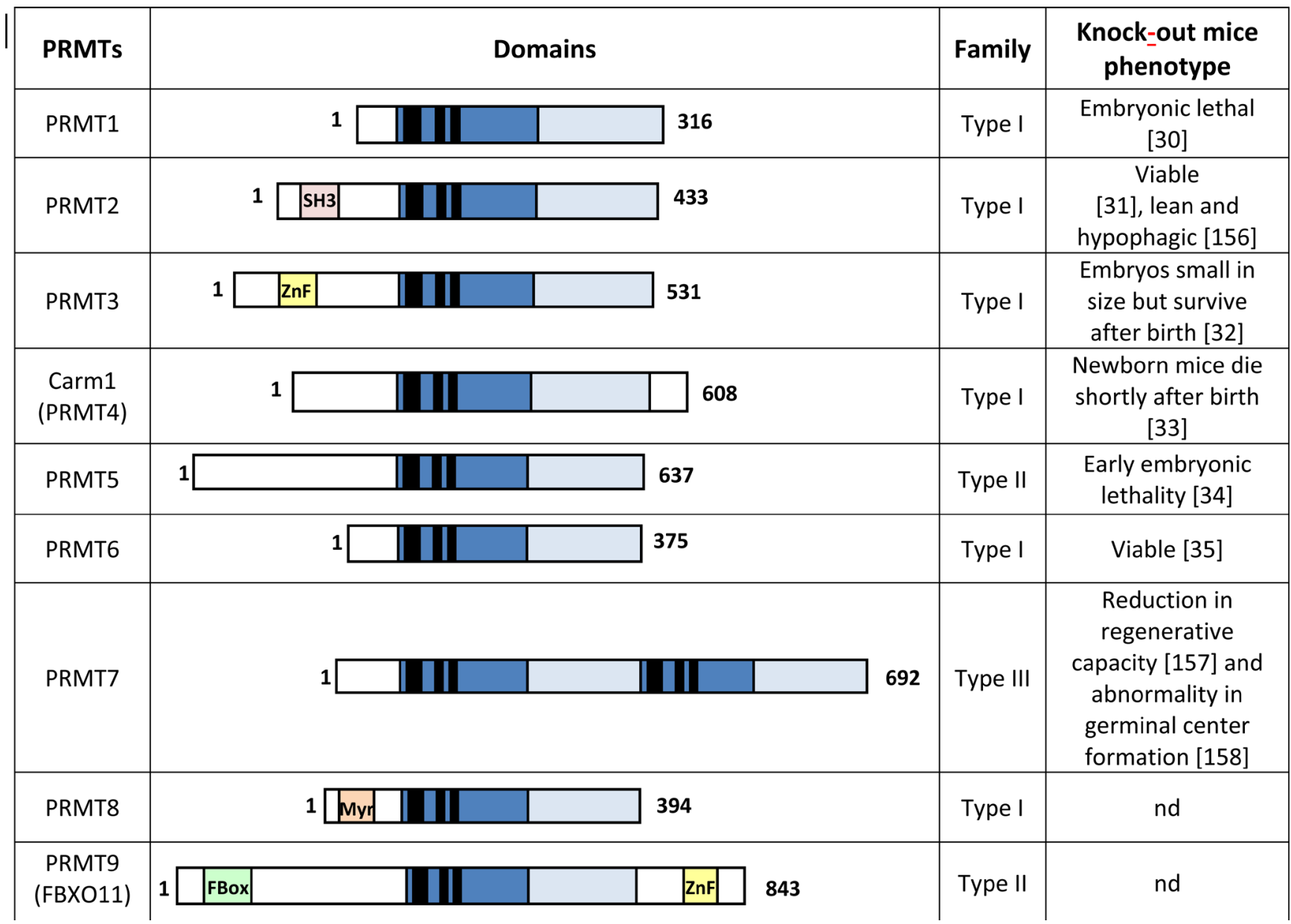

The catalytic methyltransferase domains (light and dark blue) contain a number of highly conserved motifs (black) that are important for the enzymatic reaction. Additional motifs: SH3 domain (SH3), zinc finger domain (ZnF), myristoylation motif (Myr), FBox motif. nd for non-determined.

such as signal transduction, protein localization, gene expression regulation, DNA damage repair and RNA metabolism (for review [18, 19]), several studies have demonstrated that PRMTs are involved in carcinogenesis and metastasis (for review [20]). Furthermore, even though JMJD6 was identified only recently, its implication in tumorigenesis has also been reported [21-26].

\section{ARGININE METHYLATION}

\section{The enzymatic activity of PRMTs}

Over $1 \%$ of genes in the mammalian genome encode general methyltransferases [27]. Around $0.5 \%$ of arginine residues were found to be methylated in mammalian tissues [28]. So far, nine PRMTs have been identified (Table 1). Most of them are ubiquitously expressed, except for PRMT8, which is predominantly observed in the brain [29], and regulate numerous cellular processes, such as proliferation or cell differentiation (Table 2). Mice depleted of PRMTs generally display an abnormal embryonic development (Table 1) [30-35]. Notably, the loss of PRMT1 and PRMT5 leads to embryonic lethality confirming their crucial role in the development of the organism [30, 34].

PRMTs catalyze the transfer of a methyl group from a methyl donor, S-adenosylmethionine (AdoMet) to a guanidino-nitrogen atom. This reaction generates S-adenosylhomocysteine (AdoHcy) and methylated arginine. Three types of methylated arginine residues are found in mammalian cells; namely, $\omega-\mathrm{N}^{\mathrm{G}}$ monomethylarginine (MMA), $\omega-\mathrm{N}^{\mathrm{G}_{-}} \mathrm{N}^{\mathrm{G}}-$ asymmetric dimethylarginine (ADMA) and $\omega-\mathrm{N}^{\mathrm{G}}-\mathrm{N}^{\prime}{ }^{\mathrm{G}}$-symmetric dimethylarginine (SDMA) (Figure 1). PRMTs are classified into three groups of enzymes (Types I, II and III) according to the type of methylation they catalyze. All of these types produce MMA; additionally, Type I PRMTs (PRMT1, PRMT2, PRMT3, Carm1 (PRMT4), PRMT6 and PRMT8) are responsible for producing 


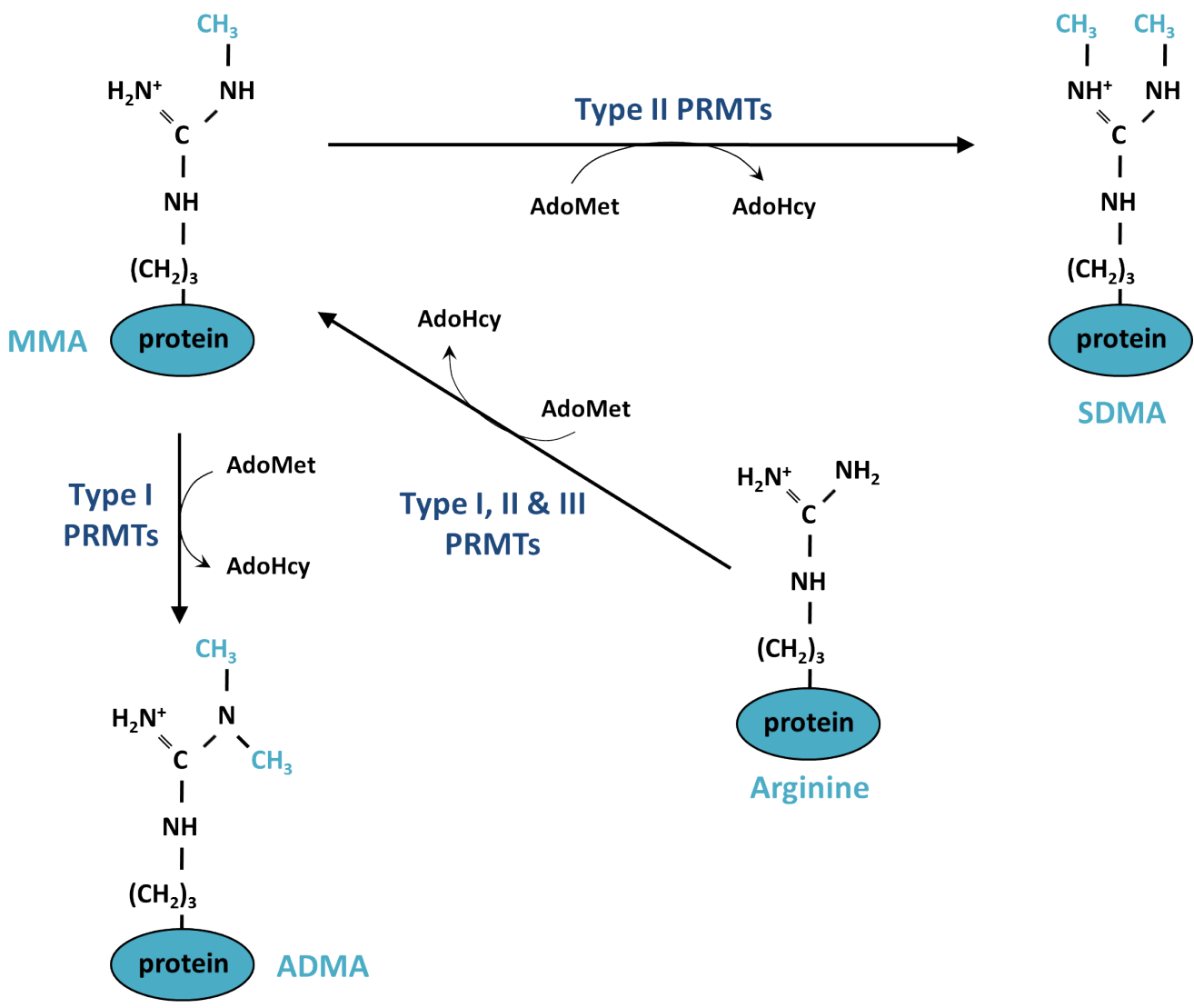

Figure 1: Mechanism of protein methylation on arginine residues. Monomethylation (MMA) is catalyzed on one of the terminal guanidino-nitrogen atom of an arginine by Type I, II and III protein arginine methyltransferase (PRMTs). The enzymatic reaction consumes a methyl donor, S-adenosylmethyionine (AdoMet) and generates S-adenosylhomocysteine (AdoHcy). Type I PRMTs generate asymmetric dimethylation (ADMA) and Types II PRMTs are responsible for symmetric dimethylation (SDMA).

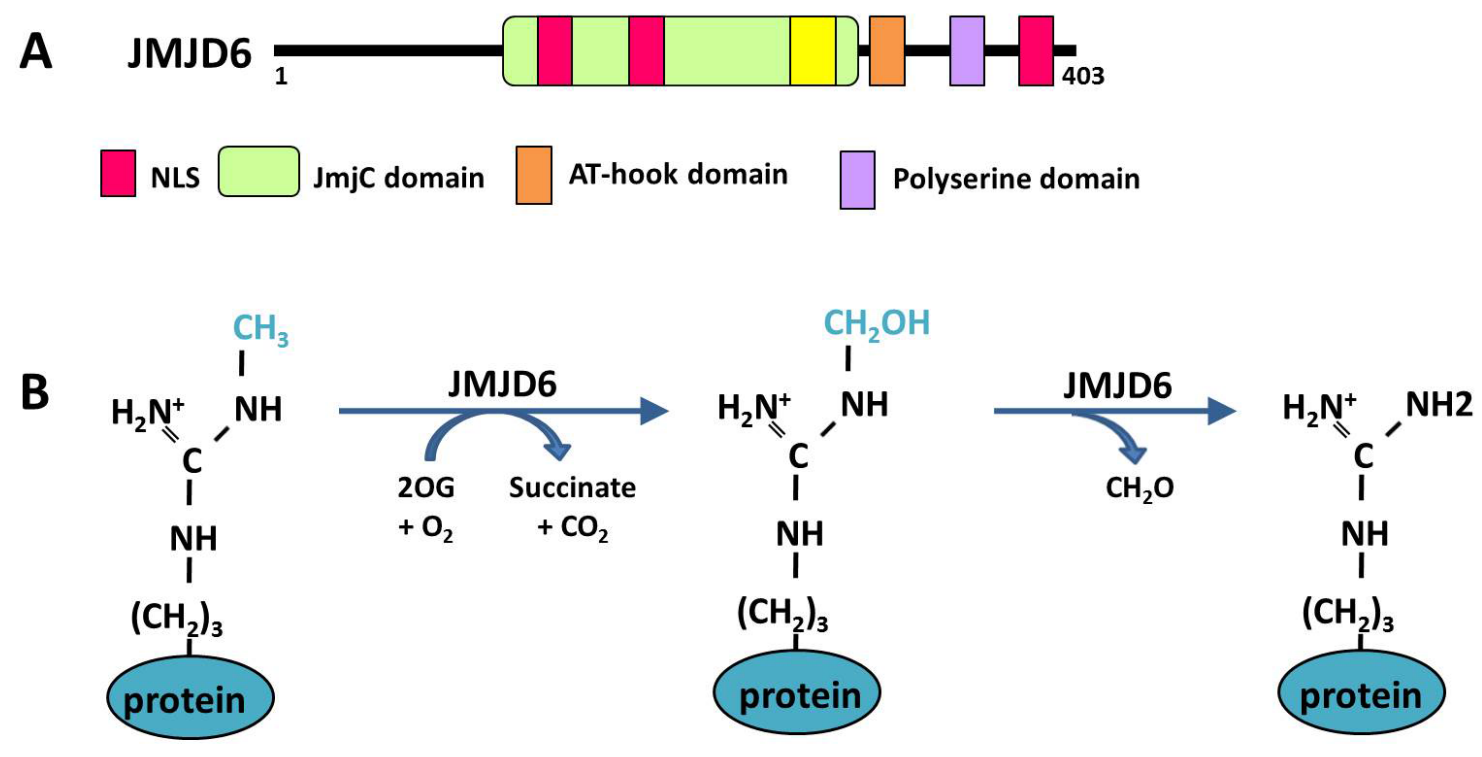

Mono methyl arginine

Unmodified arginine

Figure 2: Functional domains and demethylase activity of JMJD6. A. The different functional domains of the JMJD6 protein are presented. NLS: Nuclear localization signal. B. Demethylation reaction of a monomethylated arginine is catalyzed by JMJD6 within 2 steps. First JMJD6 hydroxylates the methyl group consuming oxoglutarate (2OG), then a deformylation reaction produces formaldehyde $\left(\mathrm{CH}_{2} \mathrm{O}\right)$ leading to an unmodified arginine. 
Table 2: Arginine methylated substrates linked with cancer

\begin{tabular}{|c|c|c|c|}
\hline PRMTs & Substrates & Effects of arginine methylation & References \\
\hline PRMT1 & $\begin{array}{l}\text { BRCA1 } \\
\text { Mre11, 53BP1 } \\
\text { Smad6 } \\
\text { Foxo1, Bad } \\
\text { ER } \alpha \\
\text { H4R3 } \\
\text { Axin } \\
\text { hnRNPK } \\
\text { RUNX1 } \\
\text { STAT1 } \\
\text { FAM98A } \\
\text { INCENP } \\
\text { H4R3 } \\
\text { EGFR } \\
\end{array}$ & $\begin{array}{l}\text { Affects the tumor suppressor ability of BRCA1. } \\
\text { Regulates DNA damage response } \\
\text { Initiates BMP-Induced Smad Signaling } \\
\text { Impeeds Akt phosphorylation } \\
\text { Prerequisite for Akt activation } \\
\text { Allows the binding of TDRD3 } \\
\text { Stabilization from proteosomal degradation } \\
\text { Negatively regulates cell apoptosis } \\
\text { Prevent the corepressor SIN3A binding } \\
\text { IFNalpha/beta-induced transcription } \\
\text { Required for tumor cell migration, invasion and colony formation } \\
\text { Promotes mitosis } \\
\text { Transcriptional activation of ZEB1 (promotes EMT) } \\
\text { Enhances EGF binding, dimerization and signaling activation }\end{array}$ & $\begin{array}{l}{[58]} \\
{[59,60]} \\
{[67]} \\
{[64,65]} \\
{[61-63]} \\
{[68]} \\
{[66]} \\
{[69]} \\
{[70]} \\
{[71]} \\
{[72]} \\
{[73]} \\
{[56]} \\
{[74]} \\
\end{array}$ \\
\hline PRMT2 & STAT3 & Regulation of leptin signaling & {$[156]$} \\
\hline PRMT3 & $\mathrm{rpS} 2$ & Inhibits ubiquitination of ribosomal protein $\mathrm{S} 2(\mathrm{rpS} 2)$ & [159] \\
\hline $\begin{array}{l}\text { Carm1 } \\
\text { (PRMT4) }\end{array}$ & $\begin{array}{l}\text { H3R17 } \\
\text { SRC3, p300/CBP } \\
\text { BAF155 } \\
\text { SOX2 } \\
\text { PAX7 } \\
\text { HSP70 } \\
\text { Carm1 itself } \\
\text { RNA polymerase II } \\
\text { MED12 } \\
\end{array}$ & $\begin{array}{l}\text { Transcriptional activation of E2F1 (promotes cell growth) } \\
\text { Coactivator regulation } \\
\text { Enhances tumor progression and metastasis } \\
\text { Enhances self-association of SOX2 } \\
\text { Allows MLL1/2 recruitment during stem cell division } \\
\text { Regulates retinoid acid-mediated RAR } \beta 2 \text { gene activation } \\
\text { Allows coupling of transcription and mRNA splicing } \\
\text { Facilitates the expression of select RNAs } \\
\text { Sensitizes human breast cancers to chemotherapy drugs } \\
\end{array}$ & \begin{tabular}{|l}
$90]$ \\
{$[83,84]$} \\
{$[92]$} \\
{$[160]$} \\
{$[161]$} \\
{$[145]$} \\
{$[162]$} \\
{$[163]$} \\
{$[93]$} \\
\end{tabular} \\
\hline PRMT5 & $\begin{array}{l}\text { H3R8, H4R3 } \\
\text { E2F1 } \\
\text { p53 } \\
\text { PDCD4 } \\
\text { EGFR } \\
\text { CRAF } \\
\text { FEN1 } \\
\text { HOXA9 } \\
\text { RAD9 } \\
\text { p65 subunit (RelA) } \\
\text { RPS10 } \\
\text { SREBP1 }\end{array}$ & $\begin{array}{l}\text { Repress expression of tumor suppressor genes (ST7, NM23) } \\
\text { Controls growth regulation } \\
\text { Control mechanism of p53 response } \\
\text { Accelerates tumor growth } \\
\text { Contributes to attenuate EGFR-mediated ERK activation } \\
\text { Limits the ERK1/2 signal } \\
\text { Facilitates PCNA binding } \\
\text { Essential for E-selectin induction } \\
\text { Required for cellular resistance to DNA damaging stresses } \\
\text { Activates NF-kB gene expression } \\
\text { Regulates ribosome biogenesis } \\
\text { Increases growth of hepatocellular carcinoma }\end{array}$ & $\begin{array}{l}{[104,105]} \\
{[112]} \\
{[108]} \\
{[102]} \\
{[111]} \\
{[113]} \\
{[114]} \\
{[115]} \\
{[116]} \\
{[117]} \\
{[118]} \\
{[119]}\end{array}$ \\
\hline PRMT6 & $\begin{array}{l}\text { p21CDKN1A } \\
\text { HMGA1 } \\
\text { DNA polymerase } \beta \\
\text { p16 } \\
\end{array}$ & $\begin{array}{l}\text { Cytoplasmic localization / resistance to cytotoxic agents } \\
\text { nd } \\
\text { Regulates DNA base excision repair } \\
\text { Impedes the p16/CDK4 interaction and induces cell proliferation }\end{array}$ & \begin{tabular}{|l|}
$122]$ \\
{$[164]$} \\
{$[165]$} \\
{$[123]$} \\
\end{tabular} \\
\hline PRMT7 & H2AR3, H4R3 & Regulates cellular response to DNA damage & {$[166]$} \\
\hline PRMT8 & EWS & nd & {$[167]$} \\
\hline PRMT9 & SAP145 & Creates a tudor domain for SMN protein & {$[168]$} \\
\hline
\end{tabular}

BRCA1: Breast cancer gene 1, 53BP1: p53 binding protein 1, BMP: Bone morphogenetic proteins, Foxo1: forkhead box protein O1, Bad: BCL-2 antagonist of cell death, ER $\alpha$ : estrogen receptor alpha, TDRD3: Tudor Domain Containing 3, hnRNPK: Heterogeneous Nuclear Ribonucleoprotein K, RUNX1: Runt-related transcription factor 1, STAT: Signal Transducer And Activator Of Transcription, IFN: Interferon, FAM98A: Family with sequence similarity 98, member A, INCENP: Inner centromere protein, ZEB1: zinc finger E-box binding homeobox 1, EMT: Epithelial-Mesenchymal Transitions, EGFR: Epidermal Growth Factor Receptor, SRC3: steroid receptor coactivator-3, CBP: CREB binding protein, BAF155: BRG1associated factor 155, SOX: SRY-box, PAX7: Paired box 7, MLL: Mixed Lineage Leukemia, HSP70: heat shock protein 70, RAR: Retinoic acid receptor, MED12: Mediator Complex Subunit 12, PDCD4: Programmed cell death-4, ERK: Extracellular signal-regulated kinases, CRAF: Proto-oncogene C-RAF, FEN1: Flap Structure-Specific Endonuclease 1, PCNA: proliferating cell nuclear antigen, HOXA9: Homeobox A9, RPS10: Ribosomal Protein S10, SREBP1: Sterol regulatory element-binding protein 1, p21 CDKN1A: Cyclin-Dependent Kinase Inhibitor 1A, HMGA1: High Mobility Group AT-Hook 1, EWS: Ewing sarcoma, SAP145: Spliceosome-associated protein 49, SMN: Survival of Motor Neuron. 
Table 3: PRMTs dysregulation in human cancer

\begin{tabular}{|c|c|c|}
\hline PRMTs & Dysregulation in human cancers & References \\
\hline PRMT1-v1 & $\begin{array}{l}\text { Overexpressed in breast cancer, bladder cancer, pediatric acute lymphoblastic leukemia and } \\
\text { in non-small cell lung carcinomas } \\
\text { Upregulated in lung cancer and glioma tissue } \\
\text { Associated with poor prognosis of colon cancer }\end{array}$ & {$[44-47]$} \\
\hline PRMT1-v2 & $\begin{array}{l}\text { Overexpressed in breast cancer } \\
\text { Upregulated in colon cancer and associated with poor prognosis }\end{array}$ & 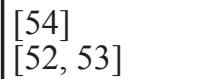 \\
\hline PRMT2 & $\begin{array}{l}\text { Overexpressed in breast cancer and associated with ER } \alpha \text {-positive tumors. } \\
\text { Overexpressed in breast cancer but decrease localization in the nucleus } \\
\text { Low expression in breast cancer compared with normal breast. }\end{array}$ & $\begin{array}{l}{[79]} \\
{[80]} \\
{[169]}\end{array}$ \\
\hline PRMT3 & nd & \\
\hline $\begin{array}{l}\text { Carm1 } \\
\text { (PRMT4) }\end{array}$ & $\begin{array}{l}\text { Overexpressed in prostate cancer, colorectal cancer, non-small cell lung carcinomas } \\
\text { Early expression in early stages of hepatocarcinogenesis. } \\
\text { Associated with poor prognosis in breast cancer }\end{array}$ & $\begin{array}{l}{[46,86,87]} \\
{[88]} \\
{[85,89]}\end{array}$ \\
\hline PRMT5 & $\begin{array}{l}\text { Upregulated in lung, gastric, bladder, colon cancer and lymphoma. } \\
\text { Overexpressed in breast cancer and epithelial ovarian cancer } \\
\text { Cytoplasmic expression is associated with high-grade subtypes of primary lung } \\
\text { adenocarcinomas }\end{array}$ & $\begin{array}{l}{[97,98]} \\
{[99,100,102]} \\
{[101]}\end{array}$ \\
\hline PRMT6 & $\begin{array}{l}\text { Overexpressed in bladder and lung cancer cells } \\
\text { Overexpressed in breast cell lines and cancer. Correlation between its expression and tumor } \\
\text { stage } \\
\text { Downregulated in invasive breast ductal carcinoma }\end{array}$ & $\begin{array}{l}{[44]} \\
{[120]} \\
{[121]}\end{array}$ \\
\hline PRMT7 & $\begin{array}{l}\text { Overexpressed in breast carcinoma cells. } \\
\text { Overexpressed in primary breast cancer and breast cancer lymph node metastasis }\end{array}$ & $\begin{array}{l}{[125]} \\
{[126]} \\
\end{array}$ \\
\hline PRMT8 & nd & \\
\hline $\begin{array}{l}\text { PRMT9 } \\
\text { (FBXO11) }\end{array}$ & nd & \\
\hline
\end{tabular}

$\mathrm{ER} \alpha$ : Estrogen Receptor alpha, nd for non-determined.

ADMA, in which the methyl groups are linked to the same guanidino nitrogen atom, while Type II PRMTs (PRMT5 and PRMT9) lead to the symmetrical addition of the methyl groups on each of the guanidino nitrogen atom of the arginine, resulting in an SDMA (Figure 1). PRMT7 is the only Type III enzyme, exclusively catalyzing the formation of MMA [36, 37].

Both nuclear and cytoplasmic proteins harboring glycine- and arginine- rich (GAR) motifs are the main targets of arginine methylation [38]. Indeed, PRMT1, PRMT3 and PRMT6 mainly recognize and methylate RGG repetitions in GAR motifs; whereas Carm1 preferentially modify arginine residues present in proline-, glycine-, and methionine (PGM) rich regions largely found in splicing factors. PRMT5 modifies substrates containing both GAR and PGM motifs [39], while PRMT7 preferentially methylates substrates with an RXR motif, consisting in a pair of arginine residues separated by one basic residue [37]. As a result of arginine methylation, GAR and PGM methylated motifs interact mainly with proteins via their Tudor domains [40]. The human genome encodes over thirty members of these proteins, including SMN, the splicing factor 30 (SPF30) and the
Tudor domains of the Tudor domain-containing proteins (TDRD), which are involved in many cellular processes (for review [41]).

\section{PRMTs and cancer}

The aberrant expression of PRMTs and the dysregulation of their enzymatic activity have been associated with several diseases (for review [16, 42]), including many types of cancers. However, exhaustive functional studies are only available for some of them, and although they have been reported in different types of cancers (Table 3), our review will focus on their link with breast cancer.

\section{PRMT1}

PRMT1 is the major PRMT, modifying around $90 \%$ of methylated arginine residues in mammalian cells [43], thereby catalyzing the majority of the ADMA. Upregulation of the protein is a feature of many types of human cancers [44-47], and high levels of PRMT1 mRNA have notably been reported in high grade breast cancers [48-53] (Table 3). Indeed, Goulet et al. found 
Table 4: JMJD6 dysregulation in human cancers

\begin{tabular}{|l|l|l|}
\hline Cancer type & Observations & References \\
\hline Colon adenocarcinoma & $\begin{array}{l}\text { Protein overexpression is associated with shorter } \\
\text { survival time (90 tumors) }\end{array}$ & {$[21]$} \\
\hline Lung adenocarcinoma & $\begin{array}{l}\text { Protein overexpression is an independent marker of poor } \\
\text { prognosis (154 tumors) }\end{array}$ & {$[22]$} \\
\hline Breast cancer & $\begin{array}{l}\text { High mRNA level is associated with poor survival } \\
\text { outcome (Supercohort containing 1954 tumors) } \\
\text { High levels of expression of JMJD6 are associated with } \\
\text { a poor prognosis for patients with tumors expressing } \\
\text { high levels of c-Myc (METABRIC database containing } \\
\text { 2000 tumors) } \\
\text { Overexpression is an independent marker of poor } \\
\text { prognosis (133 tumors) }\end{array}$ & {$[26]$} \\
\hline Oral squamous cell carcinoma & $\begin{array}{l}\text { Overexpression is an independent marker of poor } \\
\text { prognosis (16 tumors) }\end{array}$ & {$[153]$} \\
\hline
\end{tabular}

that the level of PRMT1 expression was higher in human breast tumor samples compared to adjacent normal breast tissue [47]. Furthermore, these authors demonstrated that the alternative splicing of PRMT1 pre-mRNA results in seven isoforms of the protein (PRMT1-v1 to v7), which differ in their N-terminal sequence, and are found to be dysregulated in breast cancer. This finding was later corroborated by the same team, which showed that the relative balance of PRMT1 isoforms is altered in breast cancer. For instance, PRMT1-v2 is overexpressed in breast cancer cell lines and mammary tumors and its cytoplasmic localization is linked with its key role in cell survival and invasion of breast cancer cells [54].

We can hypothesize that an overexpression of PRMT1 could trigger a hypermethylation of its substrates, accelerating the process of tumorigenesis. For example, at the transcriptional level, PRMT1 catalyzes the methylation of the R3 residue of histone H4 (H4R3), an epigenetic active mark [55]. H4R3 methylation at the ZEB1 promoter activates its transcription [56]. ZEB1 is a key transcription factor inducing the epithelial-mesenchymal transition (EMT) by repressing the transcription of E-cadherin [57]. Gao et al. demonstrated that PRMT1 is a key regulator of the EMT in breast cancer cells, promoting migration and invasion. The expression of ZEB1 is essential for PRMT1-induced EMT, migration and invasion but also for the acquisition of stem-cell-like properties [56]. Overexpression of PRMT1 may trigger cancer cells to form metastases.

A large number of non-histone substrates for PRMT1 have also been identified. BRCA1 was found to be methylated by PRMT1 in breast cancer cell lines, as well as in breast tumor samples [58]. This methylation event alters the recruitment of BRCA1 to specific promoters. Because of the involvement of its tumor suppressor activity in cell cycle transcription, DNA damage response and chromatin remodeling, a dysregulation in BRCA1 following aberrant methylation could result in genomic instability. Moreover, PRMT1 methylates the DNA repair pathway proteins MRE11 and 53BP1 (p53 binding protein 1). Methylation of MRE11 regulates its exonuclease activity on double-stranded DNA, and is required for DNA damage checkpoint control [59]. Likewise 53BP1, which is involved in DNA damage repair pathways, is methylated by PRMT1. Its methylation was shown to be essential, by following the effects of mutations of key arginine residues targeted by PRMT1 for methylation, which abrogated its binding to single or double-stranded DNA, preventing the recruitment of the DNA repair machinery [60]. Similarly, the inhibition of 53BP1 methylation, achieved by treating cells with methyltransferase inhibitors, disrupts 53BP1 localization to damaged DNA and forms fewer $\gamma \mathrm{H} 2 \mathrm{AX}$ foci [60]. In conclusion, a dysregulation in the activity of PRMT1 could lead to an accumulation of DNA damage, a well-established cause of tumorigenesis.

PRMT1 is also largely involved in cell signaling. For instance, in estrogen signaling, the methylation of the R260 residue of ER $\alpha$ is a key step in promoting the formation of a complex containing methylated ER $\alpha / \mathrm{Src} /$ $\mathrm{PI} 3 \mathrm{~K}$, and the subsequent activation of the Akt pathway $[61,62]$. Of note, this pathway is activated in aggressive breast tumors, and the high level of expression of this complex is an independent marker of poor prognosis, associated with reduced disease-free survival, supporting the idea that ER $\alpha$ hypermethylation could trigger abnormal cell proliferation [63]. Besides, PRMT1 has also been shown to regulate Akt-mediated signaling by other mechanisms, inducing apoptosis. One such example is through the methylation of the Forkhead box O1 (FOXO1), on the R248 and R252 residues in the Akt consensus phosphorylation site, which blocks its phosphorylation on the adjacent S253 residue [64]. This 
results in the retention of the FOXO1 in the nucleus, preventing its proteasomal degradation, and consequently increasing its transcriptional activity on its targeted genes. Likewise, PRMT1 binds and methylates the BCL-2 antagonist of cell death (BAD) on residues R94 and R96, inhibiting Akt phosphorylation on the S99 residue, which in turn prevents the binding of 14-3-3 protein [65], resulting in apoptosis. Inhibition of PRMT1 thus inhibits apoptosis, which is directly linked with tumorigenesis by promoting cell survival. PRMT1 also regulates the
Wnt signaling pathway by methylating the $\mathrm{R} 378$ residue of axin, a negative regulator of this Wnt pathway [66]. Methylation of axin enhances its interaction with the glycogen synthase kinase $3 \beta$, leading to a decrease in its degradation. As an aberrant regulation of the Wnt pathway is a driver of many different cancers, it is tempting to speculate that a dysregulation in the expression of PRMT1 could be linked with tumorigenesis.

In addition, PRMT1 catalyzes the methylation of many other proteins involved in important cellular

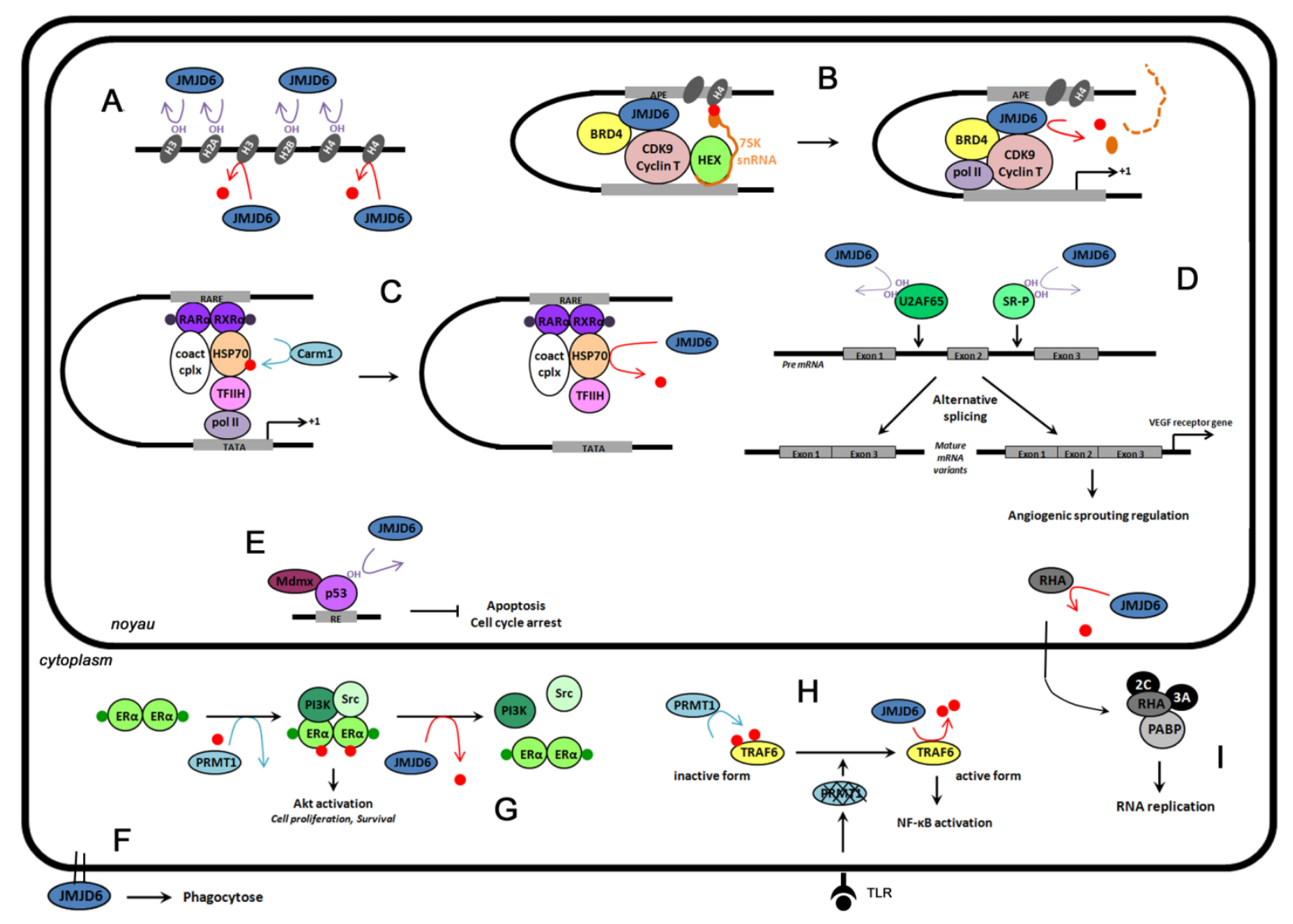

Figure 3: The functions of JMJD6 in cells. Red dots represent methylation events, and OH hydroxylation reactions. A. Epigenetic regulation. JMJD6 catalyzes the demethylation (red arrow) of histone H3 (H3R2me2) and histone H4 (H4R3me2), and lysine hydroxylation (purple arrow) of histones H3, H4, H2A and H2B. B. Regulation of transcriptional pause release on distal anti-pause enhancers (APE) of a subset of transcriptional units. JMJD6 catalyzes H4R3me2 demethylation and RNA demethylation in the cap structure of 7SK snRNA (orange dot), and is responsible for pause release and transcription elongation. C. Retinoic acid-mediated RARß2 gene regulation. Upon RA stimulation (purple dots), RAR $\alpha, \mathrm{RXR} \alpha, \mathrm{HSP} 70$, Carm 1 and coactivator complexes (Coact cplx) bind on RAR $\beta 2$ gene promoter (RARE). Carm1-methylation of HSP70 allows the recruitment of the preinitiation complex (TFIIH) and expression of RAR $\beta 2$ genes. JMJD6 demethylation reverses this process. D. Pre-mRNA splicing regulation. Lysine hydroxylation by JMJD6 of U2AF65 (K15, K276) and SR-like proteins (SR-P) regulates alternative splicing. For example, VEGR receptor gene splicing is regulated by U2AF65 hydroxylation. E. Repression of p53 transcriptional activity. JMJD6 catalyzes p53 hydroxylation. This event antagonizes p53 acetylation and promotes the interaction of p53 with the transcriptional repressor Mdmx resulting in inhibition of apoptosis and cell cycle arrest. F. Phagocytosis regulation. JMJD6 is localized at the cell surface of immature macrophages in order to regulate phagocytosis. G. Regulation of estrogen non-genomic action. Upon E2 stimulation (green dots), ER $\alpha$ is methylated by PRMT1. This event is a prerequisite to the recruitment of PI3K and Src, and the activation of Akt. JMJD6 demethylates ER $\alpha$, promoting the dissociation of the complex. H. Control of innate immune responses. Toll like receptor (TLR) ligands induce PRMT1 degradation. JMJD6 demethylates TRAF6 leading to full NF- $\mathrm{B}$ activation. I. Regulation of foot-and-mouth disease virus (FMDV) infection. FMDV infection relocalizes JMJD6 in the nucleus where it will demethylate RNA helicase A (RHA). RHA methylated exits from the nucleus and interacts in the cytoplasm with the replication machinery. 
processes [67-74] (Table 2); however, further studies are required to determine whether their methylation is linked with tumorigenesis.

\section{PRMT2}

PRMT2 was discovered through its sequence homology with PRMT1 [75], although no methyltransferase activity was associated with this enzyme at the time. Indeed, PRMT2 was only recently ascribed a Type I arginine methyltransferase activity [76], which appears to be much lower than that of PRMT1, explaining why only a limited number of substrates have been identified so far (Table 2). However, PRMT2 has been shown to enhance the transactivation of nuclear receptors, like ER $\alpha$, progesterone receptors and androgen receptors, largely involved in the development of hormone-dependent cancers [77, 78]. In effect, the expression of PRMT2 and its splice variants is increased in breast tumors compared to normal tissues. In addition, mRNA expression of PRMT2 is correlated with an ER $\alpha$ positive status [79]. Zhong et al. confirmed these results at the protein level, but found that the level of nuclear PRMT2 was lower in breast tumors in comparison with healthy tissues [80]. Furthermore, nuclear loss of PRMT2 has been shown to be associated with an increase in cyclin D1 expression and with tumor grade in invasive ductal carcinoma [80].

However, given the very few identified substrates, it is currently difficult to link the enzymatic activity of PRMT2 with tumorigenesis.

\section{Carm1 / PRMT4}

Carm1 is a Type I enzyme, which catalyzes the ADMA modification. The protein was first identified in a yeast two-hybrid screen, associated with the coactivator GRIP-1, and involved in transcriptional regulation [81]. Carm1 modifies histone $\mathrm{H} 3$ on the $\mathrm{R} 17$ residue (H3R17me2), as well as coactivators, such as p300/CBP and SRC-3 [82-84]. Several studies described an aberrant expression of Carm1 in hormone-dependent tumors, such as prostate and breast cancers $[85,86]$, but also in other types of cancers [46, 87-89] (Table 3).

Carm1 was shown to be essential for estrogeninduced cell cycle progression in breast cancer cell lines [90]. Indeed, after estrogen stimulation, nucleosomes associated with the gene encoding the critical cell cycle transcriptional regulator E2F1 are methylated by Carm1 on the R17 residue of histone H3 (H3R17me2), concomitantly with the recruitment of ER $\alpha$ and increased E2F1 gene expression. Furthermore, the recruitment of Carm1 is dependent on the SRC-3 coactivator, which is overexpressed in aggressive breast tumors concomitantly with a Carm1 overexpression [85]. Since the methylation of SRC-3 increases its activity and stability [84, 91], a high level of Carm1 could enhance the expression of genes targeted by SRC- 3 and induce cell proliferation in these tumors.
BAF155, a core subunit of the chromatin remodeling complex SWI/SNF, is another Carm1 substrate. Methylated BAF155 is directed on the chromatin of several target genes involved in the c-Myc pathway (CDCA7, COL1A2, GADD45A, DDX18, and NDRG1) and is correlated with an increase in their expression. Using an antibody specific for BAF155 methylation, the analysis of a large cohort of breast tumors revealed that BAF155 methylation was associated with cancer progression, malignancy and poor survival. Moreover, BAF155 knockdown in the aggressive breast cancer cell line MDAMB-231, impaired proliferation and migration, while the methylation of BAF155 promoted in vivo metastasis [92].

In addition, a recent study identified the RNA polymerase II mediator complex subunit (MED12), as a new substrate for Carm1, [93]. The methylation of MED12 rendered breast cancer cells sensitive to chemotherapy. These observations were validated in mouse models and in breast cancer patients. Indeed, in a clinical cohort containing 154 patients treated with 5-fluorouracil and doxorubicin, both MED12 and Carm1 protein levels predicted response to chemotherapy. Using RNA microarray analyses, the authors identified the $p 21 /$ $W A F 1$ gene among the main upregulated genes, following the depletion of MED12 or Carm1. The methylation of MED12 enhances its recruitment to the $p 21$ gene locus, in order to suppress the transcription of $p 21$, previously described to inhibit drug response [94]. The authors thus identified an unexpected new mechanism involving Carm1-methylation and drug resistance. This study demonstrated that methylation could be a sensor for drug responses in human cancers.

\section{PRMT5}

PRMT5 is the major Type II methyltransferase that catalyzes SMDA $[39,95,96]$. As was mentioned above for the others PRMTs, upregulation of the protein is associated with various cancers [97-102] (Table 3).

PRMT5 was initially shown to be involved in transcriptional repression events in the nucleus, and in snRNP biogenesis [103] in the methylosome, a large (20S) protein arginine methyltransferase complex located in the cytoplasm [96]. For example, symmetric dimethylation of histone $\mathrm{H} 4$ on the $\mathrm{R} 3$ residue (H4R3me2s) and on the R8 residue of histone H3 (H3R8me2s by PRMT5) represses the tumor suppressor gene $S T 7$ (suppression of tumorigenicity 7) $[104,105]$ and cyclin E1 [106], but also represses the cell cycle regulator CDKN2A (cyclindependant kinase inhibitor 2A) [107]. PRMT5 also induces transcriptional silencing by methylating p53 or MBD2 (methyl-CpG binding domain protein 2), altering their biochemical functions $[108,109]$. The R110 residue of the tumor suppressor protein PDCD4 (programmed cell death protein 4) is another substrate for PRMT5. In an orthotopic breast cancer model, co-expression of PDCD4 and PRMT5 accelerates tumor growth. The R110 of 
PDCD4 and the catalytic activity of PRMT5 are necessary for tumor growth. Furthermore, high levels of PDCD4 and PRMT5 expression in breast cancer were correlated with poor patient outcome [102]. Interestingly, methylation of PDCD4 by PRMT5 occurs near a S6 kinase 1 site (S67) reported to regulate $\mathrm{PDCD} 4$ stability, and could explain the impact of PDCD4 methylation in tumor growth [110].

Of note, the subcellular localization of PRMT5 changes in transformed cells; it is mostly cytoplasmic in primary and immortalized cells, and it becomes nuclear in transformed cells [104, 105]. The localization of PRMT5 could be involved in controlling cell growth and proliferation. Indeed, PRMT5 methylates EGFR on the R1175 residue, enhancing phosphorylation of the Y1173 residue, which attenuates EGFR-mediated ERK activation [111]. Methylation of R1175 creates a binding site for the phosphatase SHP1, which impedes the downstream EGFR signaling pathway. It is tempting to speculate that a relocalization of PRMT5 in the nucleus decreases R1175 methylation, triggering an increase in EGFR-mediated ERK signaling, inducing proliferation, migration and invasion in the mammary gland.

Additionally PRMT5 methylates numerous other proteins regulating normal cell processes [112-119]. We could speculate that a fine regulation of PRMT5 methylation is important to maintain the proper cell processes.

\section{PRMT6}

PRMT6 has been reported to be overexpressed in bladder, lung and breast cancer cells (Table 3) [44], and the elevated levels observed in breast tumor samples by immunohistochemistry (IHC) were correlated with tumor stage [120]. However, it was also reported that PRMT6 mRNA levels were lower in breast cancer compared to normal breast tissues [121], a discrepancy that could be due to the small number of samples analyzed in the latter study, as well as the different level of expression examined, mRNA versus protein.

PRMT6 substrates potentially linked with cancer have only recently been identified. Indeed, PRMT6 is able to methylate tumor suppressor genes, such as $p 21$ [122] and p16 [123]. Methylation of $\mathrm{p} 21$ on residue $\mathrm{R} 156$ promotes the phosphorylation of $\mathrm{T} 145$, resulting in the increase of cytoplasmic localization of p21, inhibiting its growth suppressive function, and making colon cancer cells more resistant to cytotoxic agents [122]. In addition, methylation of p16 disrupts the interaction of PRMT6 with CDK4, thus impeding the blockade of the cell cycle [123].

\section{PRMT7}

PRMT7 was initially characterized as a Type II methyltransferase, but was recently ascribed as a Type III, generating monomethylation as a final step [36, 37]. Although limited information is available on the biological functions of PRMT7, a growing body of evidence has shown that it could be linked with cancer. Indeed, PRMT7 is localized in a region known to have an aberrant copy number in metastatic breast cancers [124]. Moreover, two independent groups demonstrated that PRMT7 is overexpressed in breast carcinomas (Table 3) [125, 126]. Baldwin et al. showed that PRMT7 induces the expression of matrix metalloproteinase 9, a well-known mediator of breast cancer metastasis [126]. In parallel, Yao et al. reported that elevated PRMT7 mediates EMT through inhibition of E-cadherin expression by epigenetic modification. [125].

In summary, the overexpression of PRMTs participates in promoting oncogenic transformation by triggering the aberrant methylation of substrates involved in tumorigenesis (Table 2).

\section{ARGININE DEMETHYLATION}

The first arginine demethylase activity was unveiled by the group of Bruick in 2007 [14]. The enzyme responsible for this demethylation was JMJD6 (Jumonji domain-containing 6), which had previously been described as putative phosphatidylserine receptor (PSR) [127]. Controversy over its true function thus arose and persisted until recently (for review [128]), and will be discussed in the first part of our review on arginine demethylation, while the second part will focus on presenting new evidence linking JMJD6 and tumorigenesis (Table 4).

\section{The bifunctional JMJD6}

\section{From a phosphatidylserine receptor to an arginine demethylase}

JMJD6 was originally described as a phosphatidylserine receptor (PSR), at the level of the plasma membrane of macrophages and dendritic cells [127]. Since its discovery in the year 2000, contradictory studies have been published on the function of JMJD6. The most unexpected findings were those revealed by JMJD6 loss-of-function experiments, which were unable to confirm its involvement in the phagocytic process in mice, but showed that transgenic mice carrying JMJD6 null mutations died around birth [129-131]. Two subsequent studies reported a nuclear localization of JMJD6 [132, 133], suggesting that it could be involved in other processes. A bioinformatics analysis of JMJD6 protein in Hydra vulgaris led to the identification of three nuclear localization signals (NLS), a JmjC domain and a DNA binding domain (AT-hook domain) (Figure 2A). The Jumonji C (JMJC) domain can catalyze protein demethylation through an oxidative mechanism requiring iron Fe (II) and 2-oxoglutarate (2OG) as cofactors. Moreover, this in silico analysis also uncovered a high level of homology between JMJD6 and the FIH-1 protein (factor inhibiting HIF), which possesses a 2OG-and 
Fe (II)-dependent oxygenase activity [133], suggesting that JMJD6 could display a similar oxidative enzymatic activity (Figure 2B).

Since then, several reports have shown that JMJD6 was mainly localized in the nucleus, with a diffuse expression in the nucleoplasm, as well as in nuclear speckles [15]. Interestingly, these latter structures concentrate numerous methylated proteins [134], in addition to being enriched in RNA splicing factors. Moreover, a pool of JMJD6 is also localized in the cytoplasm and a recent publication indicated that JMJD6 could either be found in the cytoplasm or in the nucleus according to the cellular context [135]. Indeed, it appears that, JMJD6 is localized at the cell surface in immature macrophages, in order to regulate phagocytosis, and then translocates into the nucleus of differentiated cells. Such a mechanism was also unveiled for HER2 that translocate into the nucleus via its NLS [136].

\section{The enzymatic activities of JMJD6}

As mentioned above, arginine demethylation was first described in 2007, on histone proteins, modifying the $\mathrm{R} 2$ and $\mathrm{R} 3$ residues of histone $\mathrm{H} 3$ and $\mathrm{H} 4$, respectively (Figure 3A) [14]. Similarly to the lysine demethylases belonging to the JmjC family, JMJD6 is a JmjC-containing iron- and 2-oxoglutarate-dependent dioxygenase. During a JMJD6-demethylation event, hydroxylation of the methyl group is immediately followed by a deformylation producing formaldehyde (Figure 2B).

Subsequently, some reports challenged the original demethylase activity of JMJD6. Indeed, they demonstrated that JMJD6 also acts as a hydroxylase by catalyzing the lysyl-5-hydroxylation of the splicing regulatory factor U2AF65 (U2 small nuclear ribonucleoprotein auxiliary factor 65-kilodalton), of multiple lysyl residues on histone $\mathrm{H} 3$ and $\mathrm{H} 4$ tails and of the tumor suppressor p53 (Figure 3A, 3D, 3E) [15, 137-139]. In 2009, Webby et al. demonstrated that the hydroxylation of U2AF65 on the lysine K15 and K276 residues regulates RNA splicing of some specific genes [15]. Different groups then reported the role of JMJD6 in the regulation of RNA splicing $[138,140,141]$. JMJD6 also catalyzes the hydroxylation of lysine residues of histones H2A and H2B [137, 139]. Interestingly these authors showed that hydroxylation of lysine residue inhibits methylation and, inversely monomethylation of lysine residues blocks hydroxylation by JMJD6, suggesting that JMJD6 is essential to maintain the "histone code" [139].

However, even if the demethylase activity of JMJD6 was questioned for almost a decade, the group led by Rosenfeld and others clearly validated this enzymatic activity in 2013 [142-146]. Indeed, this team demonstrated the removal of ADMA and SDMA from H4R3me2 by JMJD6, and described a novel removal of the methyl group from the cap structure of 7SK snRNA on antipause enhancers [142] (Figure 3B). In their study, JMJD6 specifically catalyzed the demethylation of H4R3me2 in a panel of modified histones, while the enzymatically inactive JMJD6 mutant (H187A) had no effect on this modification. This result, initially controversial, is now well recognized by the scientific community, since two independent groups demonstrated the same demethylation of H4R3me2, and validated these observations by mass spectrometry. In parallel, our group identified the first non-histone target of JMJD6, namely ER $\alpha$ [143] (Figure 3G). We demonstrated that JMJD6 (i) interacted with methylated $\mathrm{ER} \alpha(\operatorname{metER} \alpha)$, (ii) was part of the previously described metER $\alpha / \mathrm{Src} / \mathrm{PI} 3 \mathrm{~K}$ complex, and (iii) demethylates metER $\alpha$. Recently, Lawrence et al. showed that JMJD6 demethylates the RNA helicase A (RHA) in foot-and-mouth disease virus infected cells, in order to facilitate viral replication [144] (Figure 3I). More recently, Gao et al. showed that JMJD6 demethylates the HSP70 (heat-shock protein of $70 \mathrm{kDa}$ ) on $\mathrm{R} 469$ residue in vitro and in cell lines (Figure 3C) [145]. Indeed, JMJD6 knockdown in cells increased the level of methylated HSP70, while the in vitro demethylation assay using recombinant JMJD6 protein was confirmed by mass spectrometry. These authors also showed that the demethylation of HSP70 reverses the recruitment of the preinitiation complex (TFIIH) to and expression of the RAR $\beta 2$ (retinoic acid receptor) gene, the functions of which are driven by the Carm1-methylation of HSP70 [145]. The transcription factor PAX3 is also a potential substrate for JMJD6 [147]. Indeed, the authors demonstrated that the loading of PAX3 onto mitotic chromosomes requires arginine methylation, which is regulated by the catalytic activity of JMJD6.

While a majority of studies have reported that the catalytic activity of JMJD6 is mainly localized in the nucleus, JMJD6 also demethylates cytoplasmic substrates. For example, JMJD6 interacts with and demethylates methylated ER $\alpha$ in the cytoplasm of breast epithelial cells [143]. More recently, a novel cytoplasmic substrate for JMJD6 was identified, namely TRAF6 (Tumor Necrosis Factor (TNF) Receptor-associated Factor 6 (Figure 3H), which is demethylated in response to toll-like receptor ligands in order to regulate the innate immune system [146]

So far most investigations have focused on the involvement of JMJD6 in asymmetric demethylation, with the identification of histone and non-histone substrates like ER $\alpha$, RHA, HSP70 and TRAF6. The role of JMJD6 in symmetrical demethylation is less clear, since only one substrate was identified, namely histone $\mathrm{H} 4$ symmetrically dimethylated on R3 (H4R3m2s) [15, 138]. Our group found that the depletion of JMJD6 does not affect global symmetric dimethylation levels, but impacts global asymmetric dimethylation levels, supporting the idea that JMJD6 preferentially demethylates asymmetric dimethylation. However, even if JMJD6 possesses a $\mathrm{JmjC}$ domain, it is clearly not involved in histone lysine demethylation [148]. 
Finally, we speculate that the controversy around the demethylase activity of JMJD6 came from its low efficiency in demethylating substrates in vitro. Several findings concur with this hypothesis. (i) Structurally, JMJD6 shares a JmjC domain similar to lysine demethylases [14, 149], but lacks a consensus domain known to target methylated arginine proteins, as Tudor domain for example. Consequently, JMJD6 may require binding partners to target its substrates. This has also been reported for PRMT5 and for the lysine demethylase LSD1, which requires MEP50 and Co-REST to become fully active [103, 150]. Interestingly, Unoki and colleagues recently demonstrated that JMJD6 requires a partner to recognize modified histones and catalyze their hydroxylation, namely UHRF1 (ubiquitin-like with PHD and RING finger domains) [139]. (ii) Post-translational modifications may also regulate its activity. For example, the hydroxylase activity of JMJD6 is required for its own oligomerization $[151,152]$, an essential event for its demethylase activity. Of note, we personally observed that the quality/purity of the recombinant protein preparation and the use of fresh demethylation buffer containing Fe (II), $2 \mathrm{OG}$ and ascorbate are two important steps to optimize the demethylation assay.

Altogether, these findings clearly demonstrate the bifunctional enzymatic activities of JMJD6, its distribution throughout the cells in both the nucleus and the cytoplasm, and its implication in major biological processes (Figure 3 ). And although some of these processes have only recently been uncovered, the association between JMJD6 dysregulation and cancer has already been reported.

\section{JMJD6 and cancer}

Indeed, the expression profile of JMJD6 has been investigated by several groups in different types of cancers (Table 4). Using tissue microarrays, Wang and colleagues found that JMJD6 is upregulated in all types of carcinoma including breast, liver, lung, renal, pancreatic, colon, esophageal, rectal and gastric cancers [21]. However its highest level of expression was found in colon adenocarcinoma, and the authors identified that a high level of JMJD6 expression was associated with a shorter survival time [21]. Furthermore, the expression of JMJD6 expression was confirmed to be higher in lung adenocarcinomas than in normal tissue [22]. Likewise, it was also described that JMJD6 was highly expressed in oral squamous cell carcinoma (OSCC) compared to normal tissues [153]. These authors demonstrated that JMJD6 was positively correlated with oral carcinogenesis, was enriched in oral cancer stem cells (CSC), and was identified as a novel regulator of OSCCs.

In addition several reports have shown that an overexpression of JMJD6 is associated with a poor prognosis in different cancers [22-25], in particular, in lung and oral cancer $[22,25]$. In breast cancer, a high level of JMJD6 mRNA expression was linked with tumors with poor outcomes [24, 26], which was confirmed at the protein level, after analyzing 133 breast tumors [23]. Overall these findings strongly indicate that JMJD6 is involved in breast tumorigenesis, and, more precisely, it was shown that the overexpression of the catalytically inactive JMJD6 mutant resulted in a loss of its deleterious effects on proliferation, migration and invasion [23]. In addition, a recent study demonstrated that JMJD6 cooperates with c-Myc to enhance tumorigenesis. Indeed, JMJD6 binds to the p19ARF promoter, where it demethylates H4R3me2a leading to the inhibition of c-Myc-induced apoptosis under various stress conditions [26]. Of note, co-expression of high levels of JMJD6 and c-Myc is associated with poor prognosis for patients harboring ER $\alpha$-positive breast tumors.

However, we cannot distinguish from the latter study, which of its enzymatic activities is involved in breast tumorigenesis, since the mutated amino acids are required for iron binding, a prerequisite event for both arginine demethylation and lysine hydroxylation. Nevertheless, overexpression of JMJD6 in several cancers may trigger excessive demethylation and/or hydroxylation of several substrates involved in tumorigenesis. For example, JMJD6 demethylates ER $\alpha$, suggesting that the demethylase activity of JMJD6 could disturb nongenomic estrogen signaling, a pathway activated in aggressive breast tumors [63]. However, JMJD6 has been shown to promote colon carcinogenesis through its hydroxylase activity. Indeed, JMJD6 interacts with the tumor suppressor p53 and catalyzes its hydroxylation. JMJD6 knock-down represses p53-dependent colon cell proliferation and tumorigenesis in mice models [21]. Likewise, JMJD6 depletion results in an alternative splicing of VEGFR, generating a soluble form of the receptor, which inhibits angiogenesis by binding directly to VEGF [138]. These authors demonstrated that JMJD6 mediates alternative splicing of VEGFR by interacting with U2AF65. Since U2AF65 is hydroxylated by JMJD6 [15], we can speculate that the overexpression of JMJD6 may increase angiogenesis via its hydroxylase activity, in order to promote tumor proliferation.

In conclusion, the catalytic activities of JMJD6 are involved in cancer tumorigenesis, and we can expect that the discovery of more substrates will emphasize its link with cancer.

\section{CONCLUSIONS}

Protein arginine methylation is a PTM involved in numerous crucial cellular pathways. The altered expression and/or enzymatic activity of the PRMTs and arginine demethylase are involved in breast tumorigenesis. PRMTs are very often overexpressed in tumors, implying that knock-out experiments cannot be used to decipher their molecular impact on cancer development. 
Furthermore, tools, such as mouse models, are becoming a necessity to determine the precise role of these enzymes in cancer biology. In order to analyze the direct impact of PRMTs on cancer development and progression, mouse models overexpressing a specific PRMT in a defined organ would be essential. Specific inhibitors are also lacking. Indeed, although several PRMT inhibitors have been described, their selectivity and specificity for the different PRMTs are not optimal, and additional experiments need to be conducted to determine the efficacy of these drugs in vivo [154]. We can speculate that, similarly to histone deacetylase (HDAC) inhibitors [155], PRMT inhibitors could be used in therapeutic strategies in the future. Because of the clear involvement of arginine methylation in cancer, the development and validation of such drugs in clinical trials may represent the next challenge in this field of research. Additionally, numerous events regulate PRMTs, such as their interaction with some regulatory proteins, miRNAs, or other PRMTs, which could also be targeted to disrupt their enzymatic activities. Likewise, JMJD6 is also overexpressed in several cancers, such as breast, oral, lung and colon cancer [21-25]. Of interest, the COSMIC database referenced a mutation of JMJD6 on $\mathrm{H} 187$ residue in kidney carcinoma, which participates in the binding of Fe (II), and could impair its enzymatic activity. However, there are currently no data available to distinguish which of its enzymatic activities is specifically impaired. An effort should be made to understand the regulation of the enzymatic activities of JMJD6 and to develop specific inhibitors of its demethylase and hydroxylase activities. Finally, for arginine methylation, protein interactions with miRNA or PTMs could dysregulate the activity of JMJD6, resulting in tumorigenesis. By improving our understanding of the regulation of JMJD6, we should therefore be able to identify novel ways to target this protein.

Nine PRMTs catalyze ADMA and SDMA modifications, and it is tempting to presume that more arginine demethylases are yet to be identified. This exciting field of research still requires more molecular investigations in addition to physiological analyses to gain a better understanding about how and why arginine methylation is dysregulated in cancer biology.

\section{ACKNOWLEDGMENTS}

MLR and LC's laboratory is funded with grants from "La Ligue contre le Cancer" and the "Fondation ARC CANCER". CP was supported by grant DK055274 from NIH to M. Michael Stallcup. We thank Brigitte Mandship and M. Michael Stallcup for proofreading of the manuscript.

\section{CONFLICTS OF INTEREST}

The authors declare no conflict of interest

\section{Author Contributions}

All the Authors contributed to the concept and design of this article. CP wrote the manuscript and designed the figures. MLR and LC gave helpful discussions on the manuscript. MLR carried out the final revision and provided important suggestions.

\section{REFERENCES}

1. AMBLER RP and REES MW. Epsilon-N-Methyl-lysine in bacterial flagellar protein. Nature. 1959; 184:56-57.

2. MURRAY K. THE OCCURRENCE OF EPSILON-NMETHYL LYSINE IN HISTONES. Biochemistry. 1964; 3:10-15.

3. Baldwin GS and Carnegie PR. Specific enzymic methylation of an arginine in the experimental allergic encephalomyelitis protein from human myelin. Science. 1971; 171(3971):579-581.

4. Brostoff S and Eylar EH. Localization of methylated arginine in the A1 protein from myelin. Proc Natl Acad Sci U S A. 1971; 68(4):765-769.

5. Kakimoto $\mathrm{Y}$ and Akazawa S. Isolation and identification of N-G,N-G- and N-G,N'-G-dimethyl-arginine, N-epsilonmono-, di-, and trimethyllysine, and glucosylgalactosyl- and galactosyl-delta-hydroxylysine from human urine. J Biol Chem. 1970; 245(21):5751-5758.

6. Lin WJ, Gary JD, Yang MC, Clarke S and Herschman HR. The mammalian immediate-early TIS21 protein and the leukemia-associated BTG1 protein interact with a protein-arginine N-methyltransferase. J Biol Chem. 1996; 271(25):15034-15044.

7. Borun TW, Pearson D and Paik WK. Studies of histone methylation during the HeLa S-3 cell cycle. J Biol Chem. 1972; 247(13):4288-4298.

8. Byvoet P, Shepherd GR, Hardin JM and Noland BJ. The distribution and turnover of labeled methyl groups in histone fractions of cultured mammalian cells. Arch Biochem Biophys. 1972; 148(2):558-567.

9. Jenuwein $\mathrm{T}$ and Allis CD. Translating the histone code. Science. 2001; 293(5532):1074-1080.

10. Annunziato AT, Eason MB and Perry CA. Relationship between methylation and acetylation of arginine-rich histones in cycling and arrested HeLa cells. Biochemistry. 1995; 34(9):2916-2924.

11. Métivier R, Penot G, Hübner MR, Reid G, Brand H, Kos $\mathrm{M}$ and Gannon F. Estrogen receptor-alpha directs ordered, cyclical, and combinatorial recruitment of cofactors on a natural target promoter. Cell. 2003; 115(6):751-763.

12. Wang Y, Wysocka J, Sayegh J, Lee YH, Perlin JR, Leonelli L, Sonbuchner LS, McDonald CH, Cook RG, Dou Y, Roeder RG, Clarke S, Stallcup MR, et al. Human PAD4 regulates histone arginine methylation levels via demethylimination. Science. 2004; 306(5694):279-283. 
13. Cuthbert GL, Daujat S, Snowden AW, Erdjument-Bromage H, Hagiwara T, Yamada M, Schneider R, Gregory PD, Tempst P, Bannister AJ and Kouzarides T. Histone deimination antagonizes arginine methylation. Cell. 2004; 118(5):545-553.

14. Chang B, Chen $\mathrm{Y}$, Zhao $\mathrm{Y}$ and Bruick RK. JMJD6 is a histone arginine demethylase. Science. 2007; 318(5849):444-447.

15. Webby CJ, Wolf A, Gromak N, Dreger M, Kramer H, Kessler B, Nielsen ML, Schmitz C, Butler DS, Yates JR, Delahunty CM, Hahn P, Lengeling A, et al. Jmjd6 catalyses lysyl-hydroxylation of U2AF65, a protein associated with RNA splicing. Science. 2009; 325(5936):90-93.

16. Bedford MT and Clarke SG. Protein arginine methylation in mammals: who, what, and why. Mol Cell. 2009; 33(1):1-13.

17. Kuhn $\mathrm{P}$ and $\mathrm{Xu} \mathrm{W}$. Protein arginine methyltransferases: nuclear receptor coregulators and beyond. Prog Mol Biol Transl Sci. 2009; 87:299-342.

18. Lee YH and Stallcup MR. Minireview: protein arginine methylation of nonhistone proteins in transcriptional regulation. Mol Endocrinol. 2009; 23(4):425-433.

19. Bedford MT and Richard S. Arginine methylation an emerging regulator of protein function. Mol Cell. 2005; 18(3):263-272.

20. Yang $\mathrm{Y}$ and Bedford MT. Protein arginine methyltransferases and cancer. Nat Rev Cancer. 2013; 13(1):37-50.

21. Wang F, He L, Huangyang P, Liang J, Si W, Yan R, Han X, Liu S, Gui B, Li W, Miao D, Jing C, Liu Z, et al. JMJD6 promotes colon carcinogenesis through negative regulation of p53 by hydroxylation. PLoS Biol. 2014; 12(3):e1001819.

22. Zhang J, Ni SS, Zhao WL, Dong XC and Wang JL. High expression of JMJD6 predicts unfavorable survival in lung adenocarcinoma. Tumour Biol. 2013; 34(4):2397-2401.

23. Poulard C, Rambaud J, Lavergne E, Jacquemetton J, Renoir JM, Trédan O, Chabaud S, Treilleux I, Corbo L and Le Romancer M. Role of JMJD6 in Breast Tumourigenesis. PLoS One. 2015; 10(5):e0126181.

24. Lee YF, Miller LD, Chan XB, Black MA, Pang B, Ong CW, Salto-Tellez M, Liu ET and Desai KV. JMJD6 is a driver of cellular proliferation and motility and a marker of poor prognosis in breast cancer. Breast Cancer Res. 2012; 14(3):R85.

25. Lee CR, Lee SH, Rigas NK, Kim RH, Kang MK, Park NH and Shin KH. Elevated expression of JMJD6 is associated with oral carcinogenesis and maintains cancer stemness properties. Carcinogenesis. 2016; 37(2):119-128.

26. Aprelikova O, Chen K, El Touny LH, Brignatz-Guittard C, Han J, Qiu T, Yang HH, Lee MP, Zhu M and Green JE. The epigenetic modifier JMJD6 is amplified in mammary tumors and cooperates with c-Myc to enhance cellular transformation, tumor progression, and metastasis. Clin Epigenetics. 2016; 8:38.

27. Katz JE, Dlaki M and Clarke S. Automated identification of putative methyltransferases from genomic open reading frames. Mol Cell Proteomics. 2003; 2(8):525-540.

28. Paik W and Kim S. (1980). Natural occurrence of various methylated amino acid derivatives. (New York: John Wiley \& sons).

29. Lee J, Sayegh J, Daniel J, Clarke S and Bedford MT. PRMT8, a new membrane-bound tissue-specific member of the protein arginine methyltransferase family. J Biol Chem. 2005; 280(38):32890-32896.

30. Pawlak MR, Scherer CA, Chen J, Roshon MJ and Ruley HE. Arginine N-methyltransferase 1 is required for early postimplantation mouse development, but cells deficient in the enzyme are viable. Mol Cell Biol. 2000; 20(13):48594869.

31. Yoshimoto $\mathrm{T}$, Boehm $\mathrm{M}$, Olive $\mathrm{M}$, Crook MF, San H, Langenickel $\mathrm{T}$ and Nabel EG. The arginine methyltransferase PRMT2 binds RB and regulates E2F function. Exp Cell Res. 2006; 312(11):2040-2053.

32. Swiercz R, Cheng D, Kim D and Bedford MT. Ribosomal protein rpS2 is hypomethylated in PRMT3-deficient mice. J Biol Chem. 2007; 282(23):16917-16923.

33. Yadav N, Lee J, Kim J, Shen J, Hu MC, Aldaz CM and Bedford MT. Specific protein methylation defects and gene expression perturbations in coactivator-associated arginine methyltransferase 1-deficient mice. Proc Natl Acad Sci U S A. 2003; 100(11):6464-6468.

34. Tee WW, Pardo M, Theunissen TW, Yu L, Choudhary JS, Hajkova P and Surani MA. Prmt5 is essential for early mouse development and acts in the cytoplasm to maintain ES cell pluripotency. Genes Dev. 2010; 24(24):2772-2777.

35. Neault M, Mallette FA, Vogel G, Michaud-Levesque J and Richard S. Ablation of PRMT6 reveals a role as a negative transcriptional regulator of the p53 tumor suppressor. Nucleic Acids Res. 2012; 40(19):9513-9521.

36. Zurita-Lopez CI, Sandberg T, Kelly R and Clarke SG. Human protein arginine methyltransferase 7 (PRMT7) is a type III enzyme forming -NG-monomethylated arginine residues. J Biol Chem. 2012; 287(11):7859-7870.

37. Feng Y, Maity R, Whitelegge JP, Hadjikyriacou A, Li Z, Zurita-Lopez C, Al-Hadid Q, Clark AT, Bedford MT, Masson JY and Clarke SG. Mammalian protein arginine methyltransferase 7 (PRMT7) specifically targets RXR sites in lysine- and arginine-rich regions. J Biol Chem. 2013; 288(52):37010-37025.

38. Najbauer J, Johnson BA, Young AL and Aswad DW. Peptides with sequences similar to glycine, arginine-rich motifs in proteins interacting with RNA are efficiently recognized by methyltransferase(s) modifying arginine in numerous proteins. J Biol Chem. 1993; 268(14):1050110509.

39. Branscombe TL, Frankel A, Lee JH, Cook JR, Yang Z, Pestka S and Clarke S. PRMT5 (Janus kinasebinding protein 1) catalyzes the formation of symmetric dimethylarginine residues in proteins. J Biol Chem. 2001; 
276(35):32971-32976.

40. Gayatri S and Bedford MT. Readers of histone methylarginine marks. Biochim Biophys Acta. 2014; 1839(8):702-710

41. Chen C, Nott TJ, Jin J and Pawson T. Deciphering arginine methylation: Tudor tells the tale. Nat Rev Mol Cell Biol. 2011; 12(10):629-642.

42. Wei H, Mundade R, Lange KC and Lu T. Protein arginine methylation of non-histone proteins and its role in diseases. Cell Cycle. 2014; 13(1):32-41.

43. Tang J, Frankel A, Cook RJ, Kim S, Paik WK, Williams $\mathrm{KR}$, Clarke $\mathrm{S}$ and Herschman HR. PRMT1 is the predominant type I protein arginine methyltransferase in mammalian cells. J Biol Chem. 2000; 275(11):7723-7730.

44. Yoshimatsu M, Toyokawa G, Hayami S, Unoki M, Tsunoda T, Field HI, Kelly JD, Neal DE, Maehara Y, Ponder BA, Nakamura Y and Hamamoto R. Dysregulation of PRMT1 and PRMT6, Type I arginine methyltransferases, is involved in various types of human cancers. Int J Cancer. 2011; 128(3):562-573.

45. Zou L, Zhang H, Du C, Liu X, Zhu S, Zhang W, Li Z, Gao C, Zhao X, Mei M, Bao S and Zheng H. Correlation of SRSF1 and PRMT1 expression with clinical status of pediatric acute lymphoblastic leukemia. J Hematol Oncol. 2012; 5:42.

46. Elakoum R, Gauchotte G, Oussalah A, Wissler MP, Clément-Duchêne C, Vignaud JM, Guéant JL and Namour F. CARM1 and PRMT1 are dysregulated in lung cancer without hierarchical features. Biochimie. 2014; 97:210-218.

47. Goulet I, Gauvin G, Boisvenue S and Côté J. Alternative splicing yields protein arginine methyltransferase 1 isoforms with distinct activity, substrate specificity, and subcellular localization. J Biol Chem. 2007; 282(45):3300933021 .

48. Miller LD, Smeds J, George J, Vega VB, Vergara L, Ploner A, Pawitan Y, Hall P, Klaar S, Liu ET and Bergh J. An expression signature for $\mathrm{p} 53$ status in human breast cancer predicts mutation status, transcriptional effects, and patient survival. Proc Natl Acad Sci U S A. 2005; 102(38):1355013555.

49. van 't Veer LJ, Dai H, van de Vijver MJ, He YD, Hart AA, Mao M, Peterse HL, van der Kooy K, Marton MJ, Witteveen AT, Schreiber GJ, Kerkhoven RM, Roberts C, et al. Gene expression profiling predicts clinical outcome of breast cancer. Nature. 2002; 415(6871):530-536.

50. Mathioudaki K, Scorilas A, Ardavanis A, Lymberi P, Tsiambas E, Devetzi M, Apostolaki A and Talieri M. Clinical evaluation of PRMT1 gene expression in breast cancer. Tumour Biol. 2011; 32(3):575-582.

51. Wang S, Tan X, Yang B, Yin B, Yuan J, Qiang B and Peng $X$. The role of protein arginine-methyltransferase 1 in gliomagenesis. BMB Rep. 2012; 45(8):470-475.

52. Papadokostopoulou A, Mathioudaki K, Scorilas A, Xynopoulos D, Ardavanis A, Kouroumalis E and Talieri
M. Colon cancer and protein arginine methyltransferase 1 gene expression. Anticancer Res. 2009; 29(4):1361-1366.

53. Mathioudaki K, Papadokostopoulou A, Scorilas A, Xynopoulos D, Agnanti N and Talieri M. The PRMT1 gene expression pattern in colon cancer. Br J Cancer. 2008; 99(12):2094-2099.

54. Baldwin RM, Morettin A, Paris G, Goulet I and Côté J. Alternatively spliced protein arginine methyltransferase 1 isoform PRMT1v2 promotes the survival and invasiveness of breast cancer cells. Cell Cycle. 2012; 11(24):4597-4612.

55. Wang H, Huang ZQ, Xia L, Feng Q, Erdjument-Bromage $\mathrm{H}$, Strahl BD, Briggs SD, Allis CD, Wong J, Tempst $\mathrm{P}$ and Zhang $\mathrm{Y}$. Methylation of histone $\mathrm{H} 4$ at arginine 3 facilitating transcriptional activation by nuclear hormone receptor. Science. 2001; 293(5531):853-857.

56. Gao Y, Zhao Y, Zhang J, Lu Y, Liu X, Geng P, Huang $\mathrm{B}$, Zhang $\mathrm{Y}$ and Lu J. The dual function of PRMT1 in modulating epithelial-mesenchymal transition and cellular senescence in breast cancer cells through regulation of ZEB1. Sci Rep. 2016; 6:19874.

57. Schmalhofer O, Brabletz $\mathrm{S}$ and Brabletz T. E-cadherin, beta-catenin, and ZEB1 in malignant progression of cancer. Cancer Metastasis Rev. 2009; 28(1-2):151-166.

58. Guendel I, Carpio L, Pedati C, Schwartz A, Teal C, Kashanchi F and Kehn-Hall K. Methylation of the tumor suppressor protein, BRCA1, influences its transcriptional cofactor function. PLoS One. 2010; 5(6):e11379.

59. Boisvert FM, Déry U, Masson JY and Richard S. Arginine methylation of MRE11 by PRMT1 is required for DNA damage checkpoint control. Genes Dev. 2005; 19(6):671676.

60. Boisvert FM, Rhie A, Richard S and Doherty AJ. The GAR motif of 53BP1 is arginine methylated by PRMT1 and is necessary for 53BP1 DNA binding activity. Cell Cycle. 2005; 4(12):1834-1841.

61. Le Romancer M, Treilleux I, Leconte N, Robin-Lespinasse Y, Sentis S, Bouchekioua-Bouzaghou K, Goddard S, Gobert-Gosse S and Corbo L. Regulation of estrogen rapid signaling through arginine methylation by PRMT1. Mol Cell. 2008; 31(2):212-221.

62. Le Romancer M, Treilleux I, Bouchekioua-Bouzaghou K, Sentis S and Corbo L. Methylation, a key step for nongenomic estrogen signaling in breast tumors. Steroids. 2010; 75(8-9):560-564.

63. Poulard C, Treilleux I, Lavergne E, BouchekiouaBouzaghou K, Goddard-Léon S, Chabaud S, Trédan O, Corbo L and Le Romancer M. Activation of rapid oestrogen signalling in aggressive human breast cancers. EMBO Mol Med. 2012; 4(11):1200-1213.

64. Yamagata K, Daitoku H, Takahashi Y, Namiki K, Hisatake K, Kako K, Mukai H, Kasuya Y and Fukamizu A. Arginine methylation of FOXO transcription factors inhibits their phosphorylation by Akt. Mol Cell. 2008; 32(2):221-231.

65. Sakamaki J, Daitoku H, Ueno K, Hagiwara A, Yamagata K 
and Fukamizu A. Arginine methylation of BCL-2 antagonist of cell death (BAD) counteracts its phosphorylation and inactivation by Akt. Proc Natl Acad Sci U S A. 2011; 108(15):6085-6090.

66. Cha B, Kim W, Kim YK, Hwang BN, Park SY, Yoon JW, Park WS, Cho JW, Bedford MT and Jho EH. Methylation by protein arginine methyltransferase 1 increases stability of Axin, a negative regulator of Wnt signaling. Oncogene. 2011; 30(20):2379-2389.

67. Xu J, Wang AH, Oses-Prieto J, Makhijani K, Katsuno Y, Pei M, Yan L, Zheng YG, Burlingame A, Brückner K and Derynck R. Arginine Methylation Initiates BMP-Induced Smad Signaling. Mol Cell. 2013; 51(1):5-19.

68. Yang $\mathrm{Y}, \mathrm{Lu} \mathrm{Y}$, Espejo $\mathrm{A}, \mathrm{Wu} \mathrm{J}, \mathrm{Xu} \mathrm{W}$, Liang $\mathrm{S}$ and Bedford MT. TDRD3 is an effector molecule for argininemethylated histone marks. Mol Cell. 2010; 40(6):10161023.

69. Yang JH, Chiou YY, Fu SL, Shih IY, Weng TH, Lin WJ and Lin $\mathrm{CH}$. Arginine methylation of hnRNPK negatively modulates apoptosis upon DNA damage through local regulation of phosphorylation. Nucleic Acids Res. 2014; 42(15):9908-9924.

70. Zhao X, Jankovic V, Gural A, Huang G, Pardanani A, Menendez S, Zhang J, Dunne R, Xiao A, ErdjumentBromage $\mathrm{H}$, Allis $\mathrm{CD}$, Tempst $\mathrm{P}$ and Nimer SD. Methylation of RUNX1 by PRMT1 abrogates SIN3A binding and potentiates its transcriptional activity. Genes Dev. 2008; 22(5):640-653.

71. Mowen KA, Tang J, Zhu W, Schurter BT, Shuai K, Herschman HR and David M. Arginine methylation of STAT1 modulates IFNalpha/beta-induced transcription. Cell. 2001; 104(5):731-741.

72. Akter KA, Mansour MA, Hyodo T, Ito S, Hamaguchi M and Senga T. FAM98A is a novel substrate of PRMT1 required for tumor cell migration, invasion, and colony formation. Tumour Biol. 2015.

73. Deng X, Von Keudell G, Suzuki T, Dohmae N, Nakakido M, Piao L, Yoshioka Y, Nakamura Y and Hamamoto R. PRMT1 promotes mitosis of cancer cells through arginine methylation of INCENP. Oncotarget. 2015; 6(34):3517335182. doi: 10.18632/oncotarget.6050.

74. Liao HW, Hsu JM, Xia W, Wang HL, Wang YN, Chang WC, Arold ST, Chou CK, Tsou PH, Yamaguchi H, Fang YF, Lee HJ, Lee HH, et al. PRMT1-mediated methylation of the EGF receptor regulates signaling and cetuximab response. J Clin Invest. 2015; 125(12):4529-4543.

75. Katsanis N, Yaspo ML and Fisher EM. Identification and mapping of a novel human gene, HRMT1L1, homologous to the rat protein arginine N-methyltransferase 1 (PRMT1) gene. Mamm Genome. 1997; 8(7):526-529.

76. Lakowski TM and Frankel A. Kinetic analysis of human protein arginine $\mathrm{N}$-methyltransferase 2: formation of monomethyl- and asymmetric dimethyl-arginine residues on histone H4. Biochem J. 2009; 421(2):253-261.
77. Qi C, Chang J, Zhu Y, Yeldandi AV, Rao SM and Zhu YJ. Identification of protein arginine methyltransferase 2 as a coactivator for estrogen receptor alpha. J Biol Chem. 2002; 277(32):28624-28630.

78. Meyer R, Wolf SS and Obendorf M. PRMT2, a member of the protein arginine methyltransferase family, is a coactivator of the androgen receptor. J Steroid Biochem Mol Biol. 2007; 107(1-2):1-14.

79. Zhong J, Cao RX, Zu XY, Hong T, Yang J, Liu L, Xiao XH, Ding WJ, Zhao Q, Liu JH and Wen GB. Identification and characterization of novel spliced variants of PRMT2 in breast carcinoma. FEBS J. 2012; 279(2):316-335.

80. Zhong J, Cao RX, Liu JH, Liu YB, Wang J, Liu LP, Chen YJ, Yang J, Zhang QH, Wu Y, Ding WJ, Hong T, Xiao XH, et al. Nuclear loss of protein arginine $\mathrm{N}$-methyltransferase 2 in breast carcinoma is associated with tumor grade and overexpression of cyclin D1 protein. Oncogene. 2014; 33(48):5546-5558.

81. Chen D, Ma H, Hong H, Koh SS, Huang SM, Schurter BT, Aswad DW and Stallcup MR. Regulation of transcription by a protein methyltransferase. Science. 1999; 284(5423):2174-2177.

82. Bauer UM, Daujat S, Nielsen SJ, Nightingale $\mathrm{K}$ and Kouzarides T. Methylation at arginine 17 of histone $\mathrm{H} 3$ is linked to gene activation. EMBO Rep. 2002; 3(1):39-44.

83. Xu W, Chen H, Du K, Asahara H, Tini M, Emerson BM, Montminy $\mathrm{M}$ and Evans RM. A transcriptional switch mediated by cofactor methylation. Science. 2001; 294(5551):2507-2511.

84. Feng Q, Yi P, Wong J and O'Malley BW. Signaling within a coactivator complex: methylation of SRC-3/AIB1 is a molecular switch for complex disassembly. Mol Cell Biol. 2006; 26(21):7846-7857.

85. El Messaoudi S, Fabbrizio E, Rodriguez C, Chuchana P, Fauquier L, Cheng D, Theillet C, Vandel L, Bedford MT and Sardet C. Coactivator-associated arginine methyltransferase 1 (CARM1) is a positive regulator of the Cyclin E1 gene. Proc Natl Acad Sci U S A. 2006; 103(36):13351-13356.

86. Hong H, Kao C, Jeng MH, Eble JN, Koch MO, Gardner TA, Zhang S, Li L, Pan CX, Hu Z, MacLennan GT and Cheng L. Aberrant expression of CARM1, a transcriptional coactivator of androgen receptor, in the development of prostate carcinoma and androgen-independent status. Cancer. 2004; 101(1):83-89.

87. Kim YR, Lee BK, Park RY, Nguyen NT, Bae JA, Kwon DD and Jung C. Differential CARM1 expression in prostate and colorectal cancers. BMC Cancer. 2010; 10:197.

88. Osada S, Suzuki S, Yoshimi C, Matsumoto M, Shirai T, Takahashi S and Imagawa M. Elevated expression of coactivator-associated arginine methyltransferase 1 is associated with early hepatocarcinogenesis. Oncol Rep. 2013; 30(4):1669-1674.

89. Habashy HO, Rakha EA, Ellis IO and Powe DG. The 
oestrogen receptor coactivator CARM1 has an oncogenic effect and is associated with poor prognosis in breast cancer. Breast Cancer Res Treat. 2013; 140(2):307-316.

90. Frietze S, Lupien M, Silver PA and Brown M. CARM1 regulates estrogen-stimulated breast cancer growth through up-regulation of E2F1. Cancer Res. 2008; 68(1):301-306.

91. Naeem H, Cheng D, Zhao Q, Underhill C, Tini M, Bedford MT and Torchia J. The activity and stability of the transcriptional coactivator $\mathrm{p} / \mathrm{CIP} / \mathrm{SRC}-3$ are regulated by CARM1-dependent methylation. Mol Cell Biol. 2007; 27(1):120-134.

92. Wang L, Zhao Z, Meyer MB, Saha S, Yu M, Guo A, Wisinski KB, Huang W, Cai W, Pike JW, Yuan M, Ahlquist $\mathrm{P}$ and $\mathrm{Xu} \mathrm{W}$. CARM1 methylates chromatin remodeling factor BAF155 to enhance tumor progression and metastasis. Cancer Cell. 2014; 25(1):21-36.

93. Wang L, Zeng H, Wang Q, Zhao Z, Boyer TG, Bian X and $\mathrm{Xu}$ W. MED12 methylation by CARM1 sensitizes human breast cancer cells to chemotherapy drugs. Sci Adv. 2015; 1(9):e1500463.

94. Zhang W, Kornblau SM, Kobayashi T, Gambel A, Claxton D and Deisseroth AB. High levels of constitutive WAF1/ Cip1 protein are associated with chemoresistance in acute myelogenous leukemia. Clin Cancer Res. 1995; 1(9):10511057.

95. Pollack BP, Kotenko SV, He W, Izotova LS, Barnoski BL and Pestka S. The human homologue of the yeast proteins Skb1 and Hsl7p interacts with Jak kinases and contains protein methyltransferase activity. J Biol Chem. 1999; 274(44):31531-31542.

96. Friesen WJ, Paushkin S, Wyce A, Massenet S, Pesiridis GS, Van Duyne G, Rappsilber J, Mann M and Dreyfuss G. The methylosome, a 20S complex containing JBP1 and pICln, produces dimethylarginine-modified Sm proteins. Mol Cell Biol. 2001; 21(24):8289-8300.

97. Wei TY, Juan CC, Hisa JY, Su LJ, Lee YC, Chou HY, Chen JM, Wu YC, Chiu SC, Hsu CP, Liu KL and Yu CT. Protein arginine methyltransferase 5 is a potential oncoprotein that upregulates G1 cyclins/cyclin-dependent kinases and the phosphoinositide 3-kinase/AKT signaling cascade. Cancer Sci. 2012; 103(9):1640-1650.

98. Wang L, Pal S and Sif S. Protein arginine methyltransferase 5 suppresses the transcription of the RB family of tumor suppressors in leukemia and lymphoma cells. Mol Cell Biol. 2008; 28(20):6262-6277.

99. Yang F, Wang J, Ren HY, Jin J, Wang AL, Sun LL, Diao KX, Wang EH and Mi XY. Proliferative role of TRAF4 in breast cancer by upregulating PRMT5 nuclear expression. Tumour Biol. 2015; 36(8):5901-5911.

100. Bao X, Zhao S, Liu T, Liu Y and Yang X. Overexpression of PRMT5 promotes tumor cell growth and is associated with poor disease prognosis in epithelial ovarian cancer. $\mathrm{J}$ Histochem Cytochem. 2013; 61(3):206-217.
101. Ibrahim R, Matsubara D, Osman W, Morikawa T, Goto A, Morita S, Ishikawa S, Aburatani H, Takai D, Nakajima J, Fukayama M, Niki T and Murakami Y. Expression of PRMT5 in lung adenocarcinoma and its significance in epithelial-mesenchymal transition. Hum Pathol. 2014; 45(7):1397-1405.

102. Powers MA, Fay MM, Factor RE, Welm AL and Ullman KS. Protein arginine methyltransferase 5 accelerates tumor growth by arginine methylation of the tumor suppressor programmed cell death 4. Cancer Res. 2011; 71(16):55795587.

103. Friesen WJ, Wyce A, Paushkin S, Abel L, Rappsilber J, Mann M and Dreyfuss G. A novel WD repeat protein component of the methylosome binds Sm proteins. J Biol Chem. 2002; 277(10):8243-8247.

104. Pal S, Vishwanath SN, Erdjument-Bromage H, Tempst P and Sif S. Human SWI/SNF-associated PRMT5 methylates histone $\mathrm{H} 3$ arginine 8 and negatively regulates expression of ST7 and NM23 tumor suppressor genes. Mol Cell Biol. 2004; 24(21):9630-9645.

105. Pal S, Baiocchi RA, Byrd JC, Grever MR, Jacob ST and Sif S. Low levels of miR-92b/96 induce PRMT5 translation and H3R8/H4R3 methylation in mantle cell lymphoma. EMBO J. 2007; 26(15):3558-3569.

106. Fabbrizio E, El Messaoudi S, Polanowska J, Paul C, Cook JR, Lee JH, Negre V, Rousset M, Pestka S, Le Cam A and Sardet C. Negative regulation of transcription by the type II arginine methyltransferase PRMT5. EMBO Rep. 2002; 3(7):641-645.

107. Chung J, Karkhanis V, Tae S, Yan F, Smith P, Ayers LW, Agostinelli C, Pileri S, Denis GV, Baiocchi RA and Sif S. Protein arginine methyltransferase 5 (PRMT5) inhibition induces lymphoma cell death through reactivation of the retinoblastoma tumor suppressor pathway and polycomb repressor complex 2 (PRC2) silencing. J Biol Chem. 2013; 288(49):35534-35547.

108. Jansson M, Durant ST, Cho EC, Sheahan S, Edelmann M, Kessler B and La Thangue NB. Arginine methylation regulates the p53 response. Nat Cell Biol. 2008; 10(12):1431-1439.

109. Le Guezennec $X$, Vermeulen $M$, Brinkman AB, Hoeijmakers WA, Cohen A, Lasonder E and Stunnenberg HG. MBD2/NuRD and MBD3/NuRD, two distinct complexes with different biochemical and functional properties. Mol Cell Biol. 2006; 26(3):843-851.

110. Dorrello NV, Peschiaroli A, Guardavaccaro D, Colburn NH, Sherman NE and Pagano M. S6K1- and betaTRCPmediated degradation of PDCD4 promotes protein translation and cell growth. Science. 2006; 314(5798):467471.

111. Hsu JM, Chen CT, Chou CK, Kuo HP, Li LY, Lin CY, Lee HJ, Wang YN, Liu M, Liao HW, Shi B, Lai CC, Bedford MT, et al. Crosstalk between Arg 1175 methylation and 
Tyr 1173 phosphorylation negatively modulates EGFRmediated ERK activation. Nat Cell Biol. 2011; 13(2):174181.

112. Cho EC, Zheng S, Munro S, Liu G, Carr SM, Moehlenbrink J, Lu YC, Stimson L, Khan O, Konietzny R, McGouran J, Coutts AS, Kessler B, et al. Arginine methylation controls growth regulation by E2F-1. EMBO J. 2012; 31(7):17851797.

113. Andreu-Pérez P, Esteve-Puig R, de Torre-Minguela C, López-Fauqued M, Bech-Serra JJ, Tenbaum S, GarcíaTrevijano ER, Canals F, Merlino G, Avila MA and Recio JA. Protein arginine methyltransferase 5 regulates ERK1/2 signal transduction amplitude and cell fate through CRAF. Sci Signal. 2011; 4(190):ra58.

114. Guo Z, Zheng L, Xu H, Dai H, Zhou M, Pascua MR, Chen QM and Shen B. Methylation of FEN1 suppresses nearby phosphorylation and facilitates PCNA binding. Nat Chem Biol. 2010; 6(10):766-773.

115. Bandyopadhyay S, Harris DP, Adams GN, Lause GE, McHugh A, Tillmaand EG, Money A, Willard B, Fox PL and Dicorleto PE. HOXA9 methylation by PRMT5 is essential for endothelial cell expression of leukocyte adhesion molecules. Mol Cell Biol. 2012; 32(7):1202-1213.

116. He W, Ma X, Yang X, Zhao Y, Qiu J and Hang H. A role for the arginine methylation of Rad9 in checkpoint control and cellular sensitivity to DNA damage. Nucleic Acids Res. 2011; 39(11):4719-4727.

117. Wei H, Wang B, Miyagi M, She Y, Gopalan B, Huang DB, Ghosh G, Stark GR and Lu T. PRMT5 dimethylates R30 of the p65 subunit to activate NF-B. Proc Natl Acad Sci U S A. $2013 ; 110(33): 13516-13521$.

118. Ren J, Wang Y, Liang Y, Zhang Y, Bao S and Xu Z. Methylation of ribosomal protein $\mathrm{S} 10$ by protein-arginine methyltransferase 5 regulates ribosome biogenesis. J Biol Chem. 2010; 285(17):12695-12705.

119. Liu L, Zhao X, Zhao L, Li J, Yang H, Zhu Z, Liu J and Huang G. Arginine methylation of SREBP1a via PRMT5 promotes de novo lipogenesis and tumor growth. Cancer Res. 2016.

120. Phalke S, Mzoughi S, Bezzi M, Jennifer N, Mok WC, Low DH, Thike AA, Kuznetsov VA, Tan PH, Voorhoeve PM and Guccione E. p53-Independent regulation of p21Waf1/ Cip1 expression and senescence by PRMT6. Nucleic Acids Res. 2012; 40(19):9534-9542.

121. Dowhan DH, Harrison MJ, Eriksson NA, Bailey P, Pearen MA, Fuller PJ, Funder JW, Simpson ER, Leedman PJ, Tilley WD, Brown MA, Clarke CL and Muscat GE. Protein arginine methyltransferase 6-dependent gene expression and splicing: association with breast cancer outcomes. Endocr Relat Cancer. 2012; 19(4):509-526.

122. Nakakido M, Deng Z, Suzuki T, Dohmae N, Nakamura $\mathrm{Y}$ and Hamamoto R. PRMT6 increases cytoplasmic localization of p21CDKN1A in cancer cells through arginine methylation and makes more resistant to cytotoxic agents. Oncotarget. 2015; 6: 30957-67. doi: 10.18632/ oncotarget.5143.

123. Wang X, Huang Y, Zhao J, Zhang Y, Lu J and Huang B. Suppression of PRMT6-mediated arginine methylation of p16 protein potentiates its ability to arrest A549 cell proliferation. Int J Biochem Cell Biol. 2012; 44(12):23332341.

124. Thomassen M, Tan Q and Kruse TA. Gene expression meta-analysis identifies chromosomal regions and candidate genes involved in breast cancer metastasis. Breast Cancer Res Treat. 2009; 113(2):239-249.

125. Yao R, Jiang H, Ma Y, Wang L, Du J, Hou P, Gao Y, Zhao L, Wang G, Zhang Y, Liu DX, Huang B and Lu J. PRMT7 induces epithelial-to-mesenchymal transition and promotes metastasis in breast cancer. Cancer Res. 2014; 74(19):56565667.

126. Baldwin RM, Haghandish N, Daneshmand M, Amin S, Paris G, Falls TJ, Bell JC, Islam S and Côté J. Protein arginine methyltransferase 7 promotes breast cancer cell invasion through the induction of MMP9 expression. Oncotarget. 2015; 6(5):3013-3032. doi: 10.18632/ oncotarget.3072.

127. Fadok VA, Bratton DL, Rose DM, Pearson A, Ezekewitz RA and Henson PM. A receptor for phosphatidylserinespecific clearance of apoptotic cells. Nature. 2000; 405(6782):85-90.

128. Böttger A, Islam MS, Chowdhury R, Schofield CJ and Wolf A. The oxygenase Jmjd6--a case study in conflicting assignments. Biochem J. 2015; 468(2):191-202.

129. Böse J, Gruber AD, Helming L, Schiebe S, Wegener I, Hafner M, Beales M, Köntgen F and Lengeling A. The phosphatidylserine receptor has essential functions during embryogenesis but not in apoptotic cell removal. J Biol. 2004; 3(4):15.

130. Kunisaki Y, Masuko S, Noda M, Inayoshi A, Sanui T, Harada M, Sasazuki T and Fukui Y. Defective fetal liver erythropoiesis and $\mathrm{T}$ lymphopoiesis in mice lacking the phosphatidylserine receptor. Blood. 2004; 103(9):33623364.

131. Li MO, Sarkisian MR, Mehal WZ, Rakic P and Flavell RA. Phosphatidylserine receptor is required for clearance of apoptotic cells. Science. 2003; 302(5650):1560-1563.

132. Cui P, Qin B, Liu N, Pan G and Pei D. Nuclear localization of the phosphatidylserine receptor protein via multiple nuclear localization signals. Exp Cell Res. 2004; 293(1):154-163.

133. Cikala M, Alexandrova O, David CN, Pröschel M, Stiening $\mathrm{B}$, Cramer $\mathrm{P}$ and Böttger $\mathrm{A}$. The phosphatidylserine receptor from Hydra is a nuclear protein with potential $\mathrm{Fe}(\mathrm{II})$ dependent oxygenase activity. BMC Cell Biol. 2004; 5:26.

134. Robin-Lespinasse Y, Sentis S, Kolytcheff C, Rostan MC, Corbo L and Le Romancer M. hCAF1, a new regulator of PRMT1-dependent arginine methylation. J Cell Sci. 2007; 
120(Pt 4):638-647.

135. Zakharova L, Dadsetan S and Fomina AF. Endogenous Jmjd6 gene product is expressed at the cell surface and regulates phagocytosis in immature monocyte-like activated THP-1 cells. J Cell Physiol. 2009; 221(1):84-91.

136. Hsu SC and Hung MC. Characterization of a novel tripartite nuclear localization sequence in the EGFR family. J Biol Chem. 2007; 282(14):10432-10440.

137. Mantri M, Loik ND, Hamed RB, Claridge TD, McCullagh JS and Schofield CJ. The 2-oxoglutarate-dependent oxygenase JMJD6 catalyses oxidation of lysine residues to give 5S-hydroxylysine residues. Chembiochem. 2011; 12(4):531-534.

138. Boeckel JN, Guarani V, Koyanagi M, Roexe T, Lengeling A, Schermuly RT, Gellert P, Braun T, Zeiher A and Dimmeler S. Jumonji domain-containing protein 6 (Jmjd6) is required for angiogenic sprouting and regulates splicing of VEGF-receptor 1. Proc Natl Acad Sci U S A. 2011; 108(8):3276-3281.

139. Unoki M, Masuda A, Dohmae N, Arita K, Yoshimatsu M, Iwai Y, Fukui Y, Ueda K, Hamamoto R, Shirakawa M, Sasaki H and Nakamura Y. Lysyl 5-hydroxylation, a novel histone modification, by Jumonji domain containing 6 (JMJD6). J Biol Chem. 2013; 288(9):6053-6062.

140. Heim A, Grimm C, Müller U, Häußler S, Mackeen MM, Merl J, Hauck SM, Kessler BM, Schofield CJ, Wolf A and Böttger A. Jumonji domain containing protein 6 (Jmjd6) modulates splicing and specifically interacts with arginineserine-rich (RS) domains of SR- and SR-like proteins. Nucleic Acids Res. 2014; 42(12):7833-7850.

141. Palmer KR, Tong S, Tuohey L, Cannon P, Ye L, Hannan NJ, Brownfoot FC, Illanes SE and Kaitu'u-Lino TJ. Jumonji Domain Containing Protein 6 Is Decreased in Human Preeclamptic Placentas and Regulates sFLT-1 Splice Variant Production. Biol Reprod. 2016.

142. Liu W, Ma Q, Wong K, Li W, Ohgi K, Zhang J, Aggarwal AK and Rosenfeld MG. Brd4 and JMJD6-associated antipause enhancers in regulation of transcriptional pause release. Cell. 2013; 155(7):1581-1595.

143. Poulard C, Rambaud J, Hussein N, Corbo L and Le Romancer M. JMJD6 regulates ER methylation on arginine. PLoS One. 2014; 9(2):e87982.

144. Lawrence P, Conderino JS and Rieder E. Redistribution of demethylated RNA helicase A during foot-andmouth disease virus infection: role of Jumonji C-domain containing protein 6 in RHA demethylation. Virology. 2014; 452-453:1-11.

145. Gao WW, Xiao RQ, Peng BL, Xu HT, Shen HF, Huang MF, Shi TT, Yi J, Zhang WJ, Wu XN, Gao X, Lin XZ, Dorrestein PC, et al. Arginine methylation of HSP70 regulates retinoid acid-mediated RAR2 gene activation. Proc Natl Acad Sci U S A. 2015; 112(26):E3327-3336.

146. Tikhanovich I, Kuravi S, Artigues A, Villar MT, Dorko K, Nawabi A, Roberts B and Weinman SA. Dynamic Arginine
Methylation of Tumor Necrosis Factor (TNF) Receptorassociated Factor 6 Regulates Toll-like Receptor Signaling. J Biol Chem. 2015; 290(36):22236-22249.

147. Wu TF, Yao YL, Lai IL, Lai CC, Lin PL and Yang WM. Loading of PAX3 to Mitotic Chromosomes Is Mediated by Arginine Methylation and Associated with Waardenburg Syndrome. J Biol Chem. 2015; 290(33):20556-20564.

148. Hahn P, Wegener I, Burrells A, Böse J, Wolf A, Erck C, Butler D, Schofield CJ, Böttger A and Lengeling A. Analysis of Jmjd6 cellular localization and testing for its involvement in histone demethylation. PLoS One. 2010; 5(10):e13769.

149. Hahn P, Böse J, Edler S and Lengeling A. Genomic structure and expression of Jmjd6 and evolutionary analysis in the context of related JmjC domain containing proteins. BMC Genomics. 2008; 9:293.

150. Shi YJ, Matson C, Lan F, Iwase S, Baba T and Shi Y. Regulation of LSD1 histone demethylase activity by its associated factors. Mol Cell. 2005; 19(6):857-864.

151. Han G, Li J, Wang Y, Li X, Mao H, Liu Y and Chen CD. The hydroxylation activity of Jmjd6 is required for its homo-oligomerization. J Cell Biochem. 2012; 113(5):16631670.

152. Wolf A, Mantri M, Heim A, Müller U, Fichter E, Mackeen MM, Schermelleh L, Dadie G, Leonhardt H, Vénien-Bryan C, Kessler BM, Schofield CJ and Böttger A. The polyserine domain of the lysyl-5 hydroxylase Jmjd6 mediates subnuclear localization. Biochem J. 2013; 453(3):357-370.

153. Lee CR, Lee SH, Rigas NK, Kim RH, Kang MK, Park NH and Shin KH. Elevated expression of JMJD6 is associated with oral carcinogenesis and maintains cancer stemness properties. Carcinogenesis. 2015.

154. Hu H, Qian K, Ho MC and Zheng YG. Small Molecule Inhibitors of Protein Arginine Methyltransferases. Expert Opin Investig Drugs. 2016; 25(3):335-358.

155. Manal M, Chandrasekar MJ, Gomathi Priya J and Nanjan MJ. Inhibitors of histone deacetylase as antitumor agents: A critical review. Bioorg Chem. 2016; 67:18-42.

156. Iwasaki H, Kovacic JC, Olive M, Beers JK, Yoshimoto T, Crook MF, Tonelli LH and Nabel EG. Disruption of protein arginine N-methyltransferase 2 regulates leptin signaling and produces leanness in vivo through loss of STAT3 methylation. Circ Res. 2010; 107(8):992-1001.

157. Blanc RS, Vogel G, Chen T, Crist C and Richard S. PRMT7 Preserves Satellite Cell Regenerative Capacity. Cell Rep. 2016; 14(6):1528-1539.

158. Ying Z, Mei M, Zhang P, Liu C, He H, Gao F and Bao S. Histone Arginine Methylation by PRMT7 Controls Germinal Center Formation via Regulating Bcl6 Transcription. J Immunol. 2015; 195(4):1538-1547.

159. Choi S, Jung CR, Kim JY and Im DS. PRMT3 inhibits ubiquitination of ribosomal protein S2 and together forms an active enzyme complex. Biochim Biophys Acta. 2008; 1780(9):1062-1069. 
160. Zhao HY, Zhang YJ, Dai H, Zhang Y and Shen YF. CARM1 mediates modulation of Sox2. PLoS One. 2011; 6(10):e27026.

161. Kawabe Y, Wang YX, McKinnell IW, Bedford MT and Rudnicki MA. Carm1 regulates Pax7 transcriptional activity through MLL1/2 recruitment during asymmetric satellite stem cell divisions. Cell Stem Cell. 2012; 11(3):333-345.

162. Kuhn P, Chumanov R, Wang Y, Ge Y, Burgess RR and $\mathrm{Xu}$ W. Automethylation of CARM1 allows coupling of transcription and mRNA splicing. Nucleic Acids Res. 2011; 39(7):2717-2726

163. Sims RJ, Rojas LA, Beck D, Bonasio R, Schüller R, Drury WJ, Eick D and Reinberg D. The C-terminal domain of RNA polymerase II is modified by site-specific methylation. Science. 2011; 332(6025):99-103.

164. Miranda TB, Webb KJ, Edberg DD, Reeves R and Clarke S. Protein arginine methyltransferase 6 specifically methylates the nonhistone chromatin protein HMGA1a. Biochem Biophys Res Commun. 2005; 336(3):831-835.

165. El-Andaloussi N, Valovka T, Toueille M, Steinacher R, Focke F, Gehrig P, Covic M, Hassa PO, Schär P, Hübscher $\mathrm{U}$ and Hottiger MO. Arginine methylation regulates DNA polymerase beta. Mol Cell. 2006; 22(1):51-62.

166. Karkhanis V, Wang L, Tae S, Hu YJ, Imbalzano AN and Sif S. Protein arginine methyltransferase 7 regulates cellular response to DNA damage by methylating promoter histones $\mathrm{H} 2 \mathrm{~A}$ and $\mathrm{H} 4$ of the polymerase catalytic subunit gene, POLD1. J Biol Chem. 2012; 287(35):29801-29814.
167. Kim JD, Kako K, Kakiuchi M, Park GG and Fukamizu A. EWS is a substrate of type I protein arginine methyltransferase, PRMT8. Int J Mol Med. 2008; 22(3):309-315.

168. Yang Y, Hadjikyriacou A, Xia Z, Gayatri S, Kim D, ZuritaLopez C, Kelly R, Guo A, Li W, Clarke SG and Bedford MT. PRMT9 is a type II methyltransferase that methylates the splicing factor SAP145. Nat Commun. 2015; 6:6428.

169. Oh TG, Bailey P, Dray E, Smith AG, Goode J, Eriksson N, Funder JW, Fuller PJ, Simpson ER, Tilley WD, Leedman PJ, Clarke CL, Grimmond S, et al. PRMT2 and ROR expression are associated with breast cancer survival outcomes. Mol Endocrinol. 2014; 28(7):1166-1185. 